\title{
Vegetation Patterns and Floristic Composition along Elevation Gradient on Jabal Musa, South Sinai, Egypt
}

\author{
Fawzy Salama ${ }^{1 *}$, Monier Abd El-Ghani ${ }^{2}$, Mohamed Gadalla ${ }^{1}$, Taha Ramadan ${ }^{1}$, Hanaa Galal ${ }^{1}$, Ali Gaafar ${ }^{3}$ \\ ${ }^{1}$ Department of Botany, Faculty of Science, Assiut University, Assiut, Egypt \\ ${ }^{2}$ The Herbarium, Faculty of Science, Cairo University, Giza 12613, Egypt \\ ${ }^{3}$ Department of Botany, Faculty of Science in New Valley Branch, Assiut University, Assiut, Egypt
}

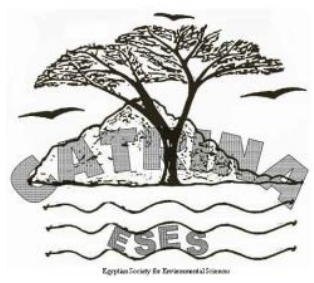

\begin{abstract}
The present study provided an investigation of the floristic analysis, vegetation composition and species distribution along $100 \mathrm{~m}$ intervals of the elevation gradient $(<1500 \mathrm{~m}$ a.s.l.- $>2000 \mathrm{~m}$ a.s.l.) on Jabal Musa (south Sinai, Egypt), and assessed the role of elevation and other soil parameters controlling plant diversity. It is a study on altitudinal variation in vegetation in a very dry climate. The vegetation structure, growth forms, and species diversity were analyzed within the 7 elevation belts on Jabal Musa area, 44 sample plots, 81 species (including one bryophyte), and 17 examined environmental factors including altitude. Asteraceae, Lamiaceae, Zygophyllaceae and Brassicaceae contributed about $41 \%$ of the species, represented in all belts. Based on the Bray-Curtis dissimilarity coefficients, it exhibited floristically homogeneous higher belts than the lower belts. Along moisture gradient, the Non Metric Multidimensional Scaling (NMDS) ordination was able to distinguish the different vegetation belts along the altitudinal gradient. The vegetation groups of the lower elevations occupied the negative side of Axis 1 while those of elaqsaa higher elevations occupied the positive end. CCA was applied to assess the relationships between soil parameters, species composition and vegetation groups. Altitude, coarse and fine sand fractions, magnesium and bicarbonates had significant correlations with diversity indices more than the others.
\end{abstract}

Keywords: Vegetation analysis, floristic composition, Mount Moses, altitudinal zonation, diversity gradient.

\section{INTRODUCTION}

The interesting location of Sinai Peninsula between two continents (Africa and Asia), with its unique physiographic features and climatic diversity, greatly affect its flora and vegetation. The topography of southern Sinai is characterized mainly by mountainous landforms that can be recognized into plains, wadis, oases and springs, salt marshes and sand dunes (Danin, 1978). The mountainous southern part of Sinai is distinguished from its northern part by its highest igneous and metamorphic peaks (Moustafa and Zaghloul, 1996) such as Jabal Katherine (2641 m a.s.1.), Jabal Musa (2285m a.s.1.) and Jabal Serbal (2070m a.s.1.). The southern part of Sinai (including Saint Katherine Mountain) is one of the most floristically diverse spots and center of endemism in the Middle East, where 44\% of Egypt's endemic plant species occur (Zohary, 1973; Boulos, 2009). To date, around 1261 species have been recorded in Sinai, of these 410 plant species have been recorded as surviving and still occurring in Saint Katherine mountainous area (Shaltout et al., 2015).

Six landforms can be distinguished: gorges, slopes, terraces, ridges, wadis and plains. Generally, sparse xerophytic vegetation relatively diverse in trees and shrubs with few annuals is reported in the mountainous area of Saint Katherine, mainly in the wadis (Moustafa and Klopatek, 1995). The vegetation along Jabal Katherine was outlined by Moustafa and Zaghloul (1996) who indicated that the wet climate of the gorge habitats are the richest in species composition among other recognized habitat types (slopes, gorges, terraces and ridges). Phytogeographically, Saharo-Arabian complex and Irano-Turanian chorotypes constitute the main bulk of the flora of southern Sinai (Abd El-Ghani and Amer, 2003).

Vegetation patterns in mountainous areas are closely related to topographical pattern as it directly influences water distribution, which controls the vegetation composition (Benhouhou et al., 2003). In the meantime, the interaction between soil characteristics and physiographic factors proved useful in the distribution of vegetation and plant communities in arid and semi-arid ecosystems (Jafari et al., 2013; Salama et al., 2015).

Elevation is the most important than other topographic factors (e.g., aspect, slope) that affect the distribution patterns of vegetation in mountain areas (Zhang and Chen, 2004). The richness of the mountainous habitats and variations in microclimatic conditions affect the global species richness (Körner, 2000), where many endemic species of both plants and animals were sheltered. Wealth of studies discussed the vegetation structure and floristic composition along altitudinal gradients; amongst others, Ghazanfar (1991) in Jabal Shams of Oman, Vetaas (1992) in the Sudan, Abd ElGhani and Abdel-Khalik (2006) in Jebel Elba of Egypt, and Hegazy et al. (2011) in Jabal Al-Akhdar of Libya. Although Jabal Musa (Mount Moses; Jabal or Gebel or Jebel in Arabic=Mountain) and Gebel Katherine are the highest peaks in southern Sinai, the latter received more attention and interest than the former which resulted in several publications (Shaltout et al., 2015). To the authors' best knowledge, limited studies on the vegetation and its environmental gradients along Jabal Musa had been undertaken. For this reason, we took the opportunity to conduct this work. Our objectives were to describe the altitudinal zonation, community composition and species diversity patterns of the vegetation of Jabal 
Musa area using techniques of multivariate analysis.

\section{MATERIALS AND METHODS}

\section{Study area and vegetation sampling design}

Sinai Peninsula lies in the arid belt of North Africa and belongs to the Saharan Mediterranean area with a true desert climate. Jabal Musa area lies within the Saint Katherine Protectorate in the southern Sinai which is located between $28^{\circ} 32^{\prime}$ to $28^{\circ} 39^{\prime} \mathrm{N}$ and $33^{\circ} 49^{\prime}$ to $33^{\circ}$ $58^{\prime}$ E (Fig. 1), with elevation ranges from 1028 to 2017 $\mathrm{m}$. It is extremely arid with long, hot and rainless summers and cool winters. Geomorphologically, the area is formed of igneous and metamorphic rocks, chiefly granites that are intensely dissected and rugged (Said, 1962). The black mountains consisting of old volcanic rocks are common in the study area which includes smooth-faced granite outcrops forming mountains such as Jabal Serbal and Jabal Ras Safsafa. The mountains in this area are dissected by faults and joints which play an important role in the movement of ground-water.

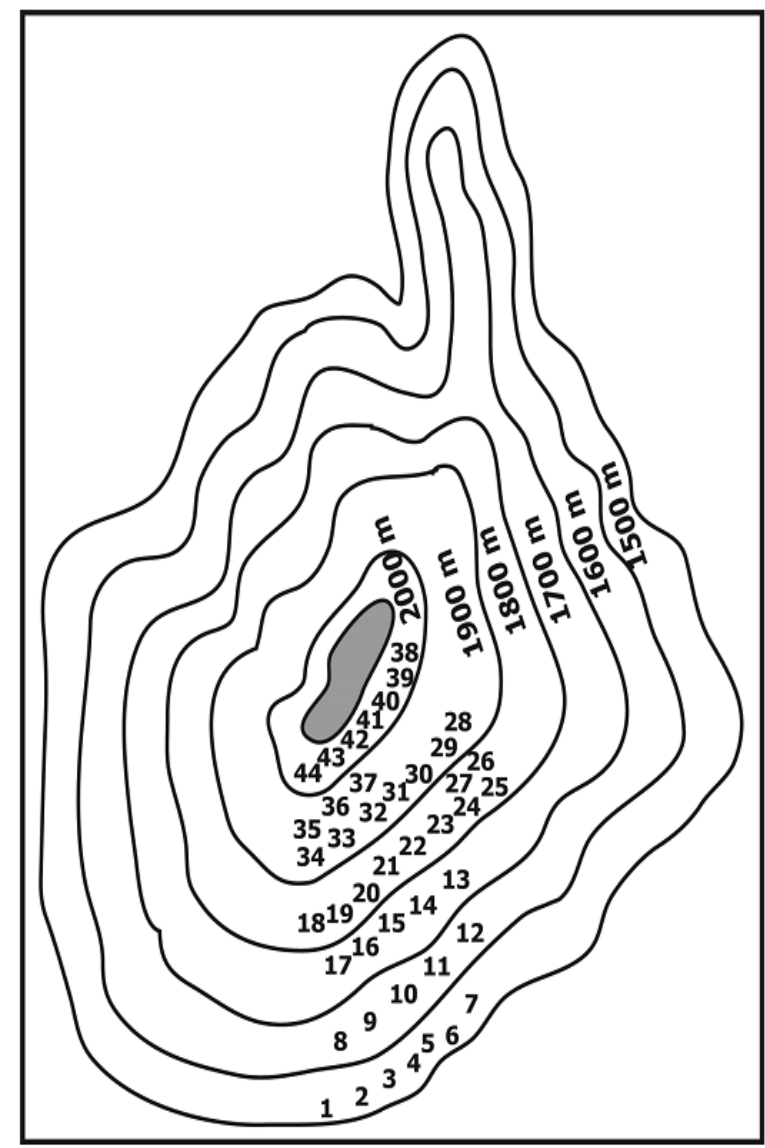

Figure (1): Contour map showing the locations of the studied 44 stands distributed along the elevation gradient of Jabal Musa.

According to Ayyad et al. (2000), the Saint Katherine area is the coolest area in Sinai due to its elevation. It receives about $100 \mathrm{~mm} /$ year (average 1970-1994 is 45 $\mathrm{mm} /$ year); the higher amounts are in the form of rain and snow.
The recorded minimum mean air temperature ranges from $-6^{\circ} \mathrm{C}$ in January-February and $36^{\circ} \mathrm{C}$ in JuneAugust. The monthly mean relative humidity ranges between $33.3 \%$ in May and June to $57.9 \%$ and $64 \%$ in February. In October 2016, rainfall recorded $28.2 \mathrm{~mm}$ which considered the wettest year after three consecutive dry years (2013-2016) in the area (personal communications; Authorities of Saint Katherine Meteorological Station).

During the growing season of 2016, 44 sample plots were randomly distributed within a relatively homogenous area in terms of vegetation and physiography. The locations of the 44 sampled plots were chosen and distributed along the altitudinal belts (Fig. 1). The area of the sampling plot varied from $20 \times 20 \mathrm{~m}$ in the lower elevations where wadi channels (flat areas) existed to 10 $\times 10 \mathrm{~m}$ in the higher elevations. An imaginary transect line was made in a north-south direction starts from the flat area at $c .1028 \mathrm{~m}$ a.s.l. in the south and ends at $c$. $2017 \mathrm{~m}$ a.s.l. in the north. The rugged topography and inaccessibility at some elevations did not allow more plots for sampling. Data on the vegetation along the studied altitudinal gradient were designed to cover the common vegetation types in each interval altitudinal belt of $100 \mathrm{~m}$.

Altogether, seven altitudinal belts were organized: level 1 (L1) >1500 $\mathrm{m}$ a.s.l., represents the flat landscape where wadis occurred; level 2 (L2) 1500-1600 m; level 3 (L3) 1600-1700 m; level 4 (L4) 1700-1800 m; level 5 (L5) 1800-1900; level 6 (L6) 1900-2000m; level 7 (L7) $<2000 \mathrm{~m}$. The distribution of the studied sample plots were as follows: 7 in L1, 5 in L2, 5 in L3, 6 in L4, 4 in L5, 11 in L6 and 6 in L7. Along the transect line, altitude above sea level, latitude and longitude of each plot were recorded using GPS (model Garmine Trex HC). Presence or absence of all species were recorded in each sample plot and their frequency (f \%) in each belt was calculated. The species dissimilarities between these belts were measured using Bray-Curtis dissimilarity coefficient.

For the analysis of biological spectrum, a 4-category growth-form system was used: trees (T), shrubs (S), perennial herbs $(\mathrm{PH})$ and annual herbs $(\mathrm{AH})$. Each species was assigned to only one category for each criterion. The significance of distribution patterns of growth forms in each elevation level along the altitudinal gradient were examined using T-test option in SPSS version 16.0 for windows. Taxonomic nomenclature was according to Täckholm (1974), and Boulos (1995, 1999, 2000 and 2002). All plants and botanical material collected were deposited in the herbarium of Assiut University (ASTU).

\section{Data treatment}

The analyses were conducted using PC-Ord version 5 for windows (McCune and Mefford, 1999) and CANOCO version 4.5 for windows (ter Braak and Šmilauer, 2002). Five related complementary multivariate approaches of classification and ordination were used to analyse and define vegetation data, and to examine their relationships with the studied environmental variables. 
First, the presence/absence stand-species data set of 44 samples and 81 species was classified by a hierarchical, agglomerative cluster analysis using the SØrensen (Bray-Curtis) distance measure and the flexible beta linkage method. This classification approach is widely used in the analysis of ecological data (McCune and Grace, 2002).

Second, an Indicator Species Analysis (ISA: Dufrêne and Legendre, 1997) was used to identify species that discriminate between cluster groups. This method calculates relative abundances (RA) and relative frequencies (RF) of species in each group and derives a percentage indicator value (IV) for each species across the groups. The higher the (IV) score, the more closely correlated the taxon was to a particular cluster group. A Monte Carlo test was used to evaluate the statistical signifycance of the maximum indicator value recorded for a given species.

Third, the significant differences among cluster groups were tested using Multi-Response Permutation Procedure (MRPP). It is a nonparametric multivariate test for differences between priori defined groups, and compares the vegetation data of sample units within the groups to the vegetation data that is randomly allocated to sample units The MRPP was applied with SØrensen (Bray-Curtis) distance measure on a matrix of 16 environmental variables, and two test statistics were calculated. The T Statistic measured between-group differentiation. A large negative $T$ value $(\leq-9.0)$ indicates high segregation (i.e., the more negative the test statistic, the greater the species differences among the groups). The A Statistic estimated the within-group homogeneity and was chance-corrected. The A statistic ranged from (0.0 1.0) with higher values indicating a high degree of homogeneity. A is usually $<0.1$ when there are a high number of species. The significance of the null hypothesis of no differences among groups was assessed by a Monte Carlo permutation procedure with 1000 permutations.

Fourth, to identify the change of the floristic composition along the altitudinal gradient, we applied the rank-based, non-metric multidimensional scaling (NMDS) using Sorensen's coefficient as the distance measure (McCune and Grace, 2002). Solutions were obtained for 1, 2 and 3 dimensions and the best solution, in terms of trade-off between complexity associated with increased dimensionality and reduction of stress, was chosen for interpretation (McCune and Mefford, 1999). Stress levels from 10-20 are considered good solutions (Peck, 2010). Significance of results was tested using a Monte Carlo permutation procedure. To explore the relationship between the ordination and the causal environmental factors, we computed correlations between the scores of each plot in the first two axes of the NMDS ordination and the corresponding values for each variable.

Fifth, canonical correspondence analysis (CCA) was performed to examine the relationships between vegetation gradients and the studied environmental variables, and a Monte Carlo permutation test (499 permutations; ter Braak, 1990) was used to test for significance of the eigenvalues of the first canonical axis. Seventeen environmental variables were examined: altitude (ALT), soil reaction $(\mathrm{pH})$, electrical conductivity (EC), moisture content (MC), gravel, coarse sand (CS), fine sand (FS), silt, clay, bicarbonates $\left(\mathrm{HCO}_{3}\right)$, chlorides $(\mathrm{Cl})$, sulphates $\left(\mathrm{SO}_{4}\right)$, phosphates $\left(\mathrm{PO}_{4}\right), \mathrm{Ca}, \mathrm{Mg}, \mathrm{Na}$ and $\mathrm{K}$. All soil parameters were checked for collinearity with other variables, and soil texture fractions (gravel, coarse sand, fine sand, silt and clay) were removed. Therefore, 12 soil variables were included in the CCA analysis. Significant variations among cluster groups were then subjected to ANOVA (One-Way Analysis of Variance) using SPSS version 16.0 for windows.

\section{Species diversity indices}

Species richness (SR) was calculated for each cluster group as the average number of species per sample plot. Based on the frequency (f \%) of each species, ShannonWiener index $\left(\mathrm{H}^{\prime}\right)$ for the relative species evenness, Simpson index (CD) for the relative concentration of species dominance and Margalef (M) alpha diversity indices for each cluster group were measured (Magurran, 2004).

Along the altitudinal gradient, species richness was also calculated as the average number of species in each belt, and Whittaker index $\left(\beta_{T}\right)$ was employed to measure beta diversity (species turnover) (Magurran, 2004). Species turnover (beta diversity) was calculated as the gain and loss of species between the adjacent $100 \mathrm{~m}$ intervals (1500-1600 m vs. $1600-1700 \mathrm{~m}, 1600-1700 \mathrm{~m}$ vs. $1700-1800 \mathrm{~m}, 1700-1800 \mathrm{~m}$ vs. $1800-1900 \mathrm{~m}, 1800-$ $1900 \mathrm{~m}$ vs. $1900-2000 \mathrm{~m}, 1900-2000 \mathrm{~m}$ vs. $>2000 \mathrm{~m}$ a.s.1.) according to the formula proposed by Wilson and Shmida (1984): $\beta_{T}=[\mathrm{g}(\mathrm{h})+1(\mathrm{~h})] / 2 \alpha$ where $\mathrm{g}(\mathrm{h})$ and l(h) are the number of species gained and lost, respectively, from one altitudinal interval to the adjacent and $\alpha$ is the average number of species in the two intervals. The software Species Diversity and Richness version 2.3 (Henderson and Seaby, 1998) was used for calculations of diversity indices.

\section{RESULTS}

\section{Floristic features and taxon diversity}

The flora of Jabal Musa included 81 species over the whole elevation gradient (Appendix 1). In general, 80 species (15 annuals and 65 perennials) belong to 69 genera and 32 families of vascular plants, and one bryophte Funaria hygrometrica were recorded. Asteraceae (15 species), Lamiaceae (9 species), Zygophyllaceae (5 species), Boraginaceae and Brassicaceae and Solanaceae (4 species for each) included the highest number of species, and constituted more than $50 \%$ of the recorded species. Asteraceae, Lamiaceae, Zygophyllaceae and Brassicaceae were represented in all belts, while Poaceae showed very low numbers. Genera with the highest number of species were Fagonia (3 species), 9 genera (Seriphidium, Ballota, Centaurea, Hyoscyamus, Iphiona, Launaea, Plantago, Pulicaria and Reseda) had 2 species, and the remaining genera included one species. The most common perennials (recorded in $>50 \%$ of sample plots) were: Seriphidium herba-alba, Zilla spinosa, Tanacetum sinaicum and 
Phlomis aurea. Common but less important annual herbs $(<50 \%$ of the sample plots) were Matthiola longipetala, Portulaca oleracea and Centaurea sinaica.

Altitudinal distribution of species numbers showed a gradual decrease from 47 in the lowest level $(<1500 \mathrm{~m})$ to 17 in the middle level $(1700-1800 \mathrm{~m})$, then started to increase (31-36 species) in the highest levels (1900$>2000 \mathrm{~m}$ ). Seriphidium herba-alba and Zilla spinosa were omnipresent. Nineteen species were consistent to lowest belt $(<1500 \mathrm{~m})$ growing in the wadis at the foot of Jabal Musa; the most common were Retama raetam, Citrullus colocynthis, Anabasis articulata, Acacia tortilis subsp. tortilis and Trichodesma africanum. Three species: Ballota saxatilis, Ephedra alata and Solanum sinaicum were consistent to the middle elevation belts between 1700 and $1900 \mathrm{~m}$ while higher elevation belts (1900-2000m) were characterized by Crataegus sinaica, Thymus decussatus, Anarrhinum pubescens and Plantago sinaica. In addition, Funaria hygrometrica was found in higher elevations between 1901 and 2000m. The Bray-Curtis coefficients of dissimilarities between the floristic composition in the studied belts (Appendix 1) indicated high values between all levels, except between L6 and L7 (higher elevations) that showed low value (high similarity).

\section{Patterns of growth-forms with altitudinal variation}

The 81 recorded species were distributed among the 4 growth-form categories as follows: 2 trees (T), 43 shrubs (S), 21 perennial herbs (PH), and 15 annual herbs $(\mathrm{AH})$. The patterns of growth forms were represented along the elevation belts (L1-L7) and shown in Figure (2). Shrubs with 43 species prevailed $(53.09 \%$ of the total flora), represented mainly by Seriphidium herbaalba, Zilla spinosa, Ballota undulata, Fagonia mollis, Tanacetum sinaicum, and Teucrium decaisnei. The perennial herbs ranked second with 21 species $(26 \%$ of the total flora), represented mainly by Ballota undulata, Phlomis aurea, and Alkanna orientalis. Trees were the rarest growth form with 2 species (Acacia tortilis subsp. raddiana and Ficus palmata), and were ceased at the lower altitudes between 1500 and $1700 \mathrm{~m}$ a.s.l. Annual herbs were represented by 15 species, of which 9 species from lower altitudes $(<1500 \mathrm{~m})$, and declined above. Trees were not significantly distributed in all belts (Appendix 1), while shrubs showed high signifycant variations. Perennial herbs were not significant in the altitudes between 1600-1900m, while annual herbs were not significantly correlated between 1800->2000m along the altitudinal gradient.

\section{Classification, indicator species analysis and descrip- tion of cluster groups}

Six cluster groups were recognized after the application of cluster analysis (A-F; Fig. 3). It was found that each cluster group can be linked to one (or more) of the studied elevation belts. The multi-response permutation procedure (MRPP) revealed that there were significant differences between these groups in the environmental matrix (chance-corrected within-group agreement $A=0.302 ; p<0.0001$ ) suggesting that these communities are distinct species assemblages. The average withingroup distance ranged between 0.37 and 0.55 indicating relatively high dispersion. The $T$ statistic was -20.253 , indicating strong dissimilarity in plant communities (cluster groups) among the studied elevation gradient. The pairwise comparisons revealed significant differences between the groups (Table 1). The six groups occupied different positions of the species space, as shown by the strong chance-corrected within-group agreement $(A)$ and test statistics $(T)$.

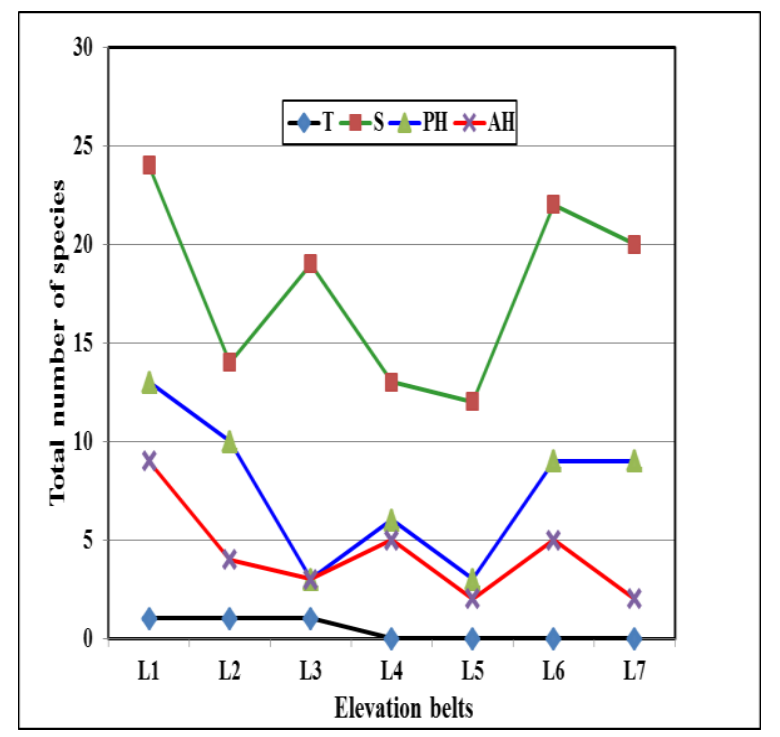

Figure (2): Distribution of growth forms in the 7 elevation belts (L1-L7). T=trees, $\mathrm{S}=$ shrubs, $\mathrm{PH}=$ perennial herbs, AH=annual herbs. $\mathrm{L} 1=1500 \mathrm{~m}, \quad \mathrm{~L} 2=1500-1600 \mathrm{~m}$, L3 $=1600-1700 \mathrm{~m}, \quad \mathrm{~L} 4=1700-1800 \mathrm{~m}, \quad \mathrm{~L} 5=1800-1900 \mathrm{~m}$, L6 $=1900-2000 \mathrm{~m}, \mathrm{~L} 7=<2000 \mathrm{~m}$.

Table (1): Multiple pairwise comparisons of the MRPP statistics of the cluster groups (A-F) based on Bray-Curtis distance. $\mathrm{A}=$ change-corrected within group agreement, $\mathrm{T}=$ difference between the observed and expected deltas.

\begin{tabular}{llll}
\hline \hline Group compared & $\boldsymbol{T}$ & $\boldsymbol{A}$ & $\boldsymbol{p}$ \\
\hline A vs. B & -6.536 & 0.223 & 0.0003 \\
A vs. C & -6.891 & 0.250 & 0.0004 \\
A vs. D & -7.409 & 0.266 & 0.0002 \\
A vs. E & -13.302 & 0.199 & 0.00000006 \\
A vs. F & -6.428 & 0.338 & 0.0005 \\
B vs. C & -5.039 & 0.236 & 0.001 \\
B vs. D & -5.489 & 0.251 & 0.0007 \\
B vs. E & -8.7757 & 0.134 & 0.000001 \\
B vs. F & -4.878 & 0.421 & 0.0029 \\
C vs. D & -5.279 & 0.206 & 0.0007 \\
C vs. E & -8.737 & 0.132 & 0.0000005 \\
C vs. F & -4.916 & 0.333 & 0.003 \\
D vs. E & -7.849 & 0.103 & 0.0000007 \\
D vs. F & -5.155 & 0.297 & 0.001 \\
E vs. F & -8.094 & 0.138 & 0.000003 \\
\hline \hline
\end{tabular}




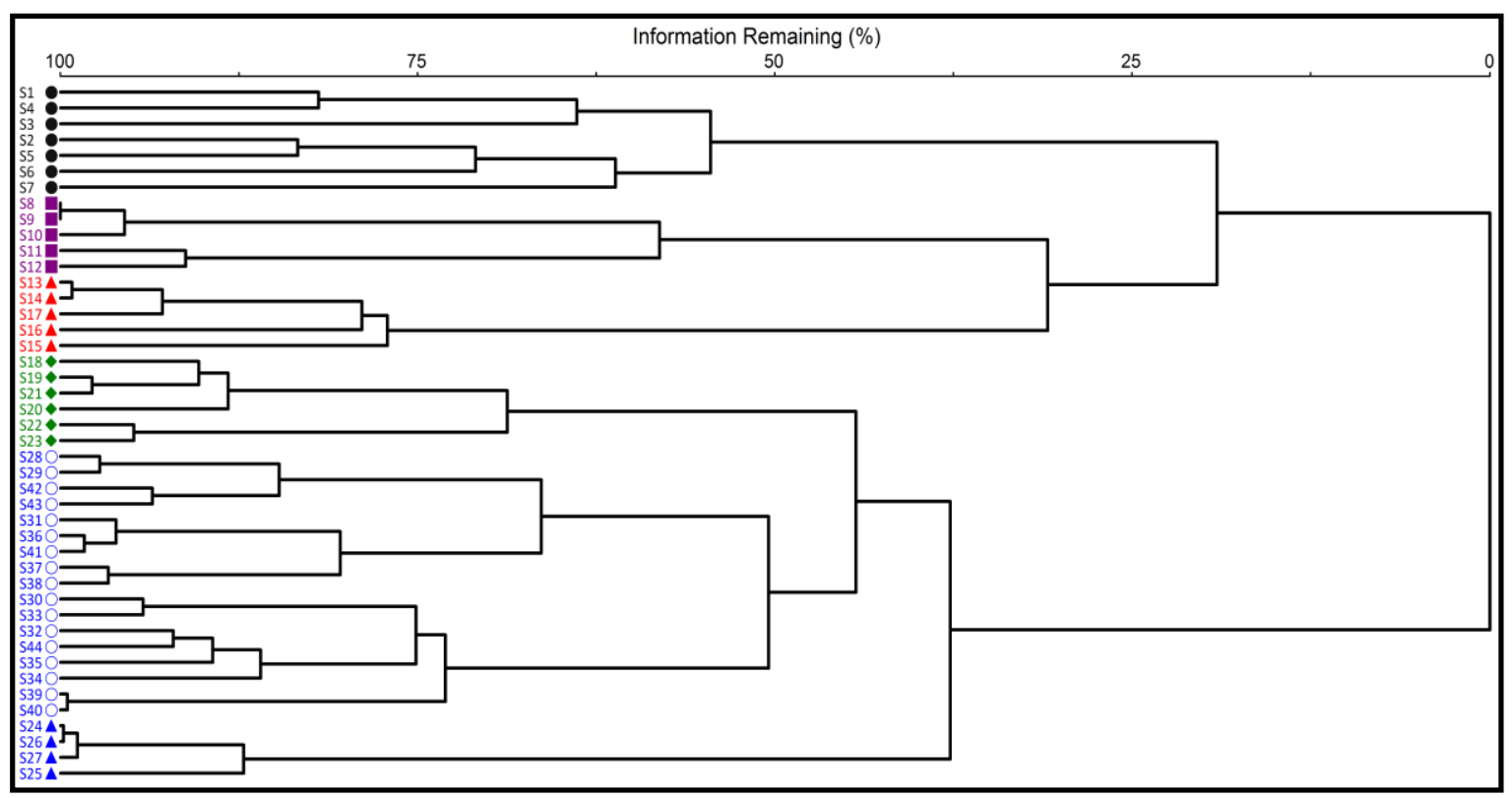

Figure (3): Bray-Curtis classification diagram of the 44 sample plots, showing the 6 separated cluster groups (A-F) within the elevation belts.

Indicator species analysis (ISA) showed that each cluster group was characterized by different indicator species (Appendix 2). The indicator values (IVs) provided an index of the relative abundance and frequency of a species correlated with cluster group. Thirty-seven species $(45.7 \%$ of the total flora) exhibited strong correlations with the cluster groups based on their IVs. High significant differences in the examined environmental attributes within the separated cluster groups were noticed (Table 2).

Group A (47 species; 9 significant indicator species) was characterized by Retama raetam, Anabasis articulata and Citrullus colocynthis (Appendix 2) inhabited the lower elevation belts (L1; <1500 m a.s.1.) at the foot of Jabal Musa, with higher contents of soil chlorides and magnesium, and lower contents of electrical conductivity, calcium and phosphates (Table 2). The tree layer included Acacia tortilis subsp. raddiana which was consistent to this group. The shrub layer formed of 9 species that were consistent to this low elevation belt, amongst others, Aerva javanica, Deverra triradiata, Iphiona scabra and Helianthemum kahiricum. The endemic perennial herb Caralluma sinaica characterizes this low elevation belt. This group included the highest number of annuals (5 out of 9), mostly common weeds of Egyptian arable lands, e.g., Chenopodium murale, Datura stramonium, Malva parviflora, Portulaca oleracea and Rumex dentatus. Group B (29 species; 8 significant indicator species) was characterized by Cleome arabica and Matthiola longipetala that occurred on sandy soil with higher levels of sodium and potassium and lower values of bicarbonates (Table 2). The tree layer is composed of Ficus palmata, and the endemic shrub Asclepias sinaica were found in this elevation belt (1500-1600m a.s.1.). Common shrubs included Alkanna orientalis, Zilla spinosa and Seriphidium herba-alba. Group C (26 species; 6 significant indicator species) was characterized by the grass Panicum turgidum and the annual herb Portulaca oleracea inhabited the gravelly, saline soil rich in their nutrient contents of sodium, potassium, magnesium and phosphates and lower levels of fine sediments between altitudes 1600 and $1700 \mathrm{~m}$. Ficus palamata formed the tree layer of this group, and 19 species formed the shrub layer (e.g., Ochradenus baccatus, Stachys aegyptiaca, Origanum syriacum, Ballota saxatilis and Teucrium decaisnei). Shrubs of Ballota saxatilis were consistent to this group. Group D (24 species; 4 significant indicator species) was indicated by Nepeta septemcrenata and Pulicaria incisa found on muddy soil rich in their fine sediments (silt and clay) with lower proportions of sand and sulphate contents between altitudes from 1700 and $1800 \mathrm{~m}$. Trees were not represented at this elevation belt, and the shrub layer was formed of 13 species; the most common were Ballota undulata and Tanacetum sinaicum. The gymnosperm shrub Ephedra alata showed consistency to this group. Common perennial herbs were Galium sinaicum and Phlomis aurea. Five annual herbs included, amongst others, Malva parviflora, Launaea capitata and Plantago amplexicaulis were recorded. Group E (41 species; 2 significant indicator species) was characterized by the shrub Plantago sinaica and the endemic perennial herb Anarrhinum pubescens (Appendix 2) occurred on the higher elevations above $1900 \mathrm{~m}$ a.s.l. inhabited soils with rich contents in gravels, moisture and calcium (Table 2). The tree layer was not repressented in this belt, while a group of 26 shrubs dominated the floristic structure of this group. Most common shrubs were Seriphidium herba-alba, Zilla spinosa, Tanacetum sinaicum, Teucrium decaisnei, Chiliadenus montanus and Thymus decussatus. Sampling plots with high moisture content of this group favored the growth of Funaria hygrometrica. 


\section{Vegetation patterns and floristic composition on Jabal Musa}

Table (2): Means and standard deviations (in brackets) of the environmental attributes, diversity indices and growth forms for each cluster group (A-E) obtained by Bray-Curtis classification.

\begin{tabular}{|c|c|c|c|c|c|c|c|}
\hline Cluster groups & $\mathbf{A}$ & $\mathbf{B}$ & $\bar{C}$ & $\mathbf{D}$ & $\mathbf{E}$ & $\mathbf{F}$ & \\
\hline Elevation (m a.s.l.) & $<1500$ & $1500-1600$ & $1600-1700$ & $1700-1800$ & $1900->2000$ & $1800-1900$ & F-ratio \\
\hline Total number of species & 47 & 29 & 26 & 24 & 41 & 17 & \\
\hline Total number of sample plots & 7 & 5 & 5 & 6 & 17 & 4 & \\
\hline \multicolumn{8}{|l|}{ Soil variables } \\
\hline Gravel & $22.0(7.64)$ & $13.4(0.89)$ & $31.0(0.71)$ & $16.17(0.41)$ & $30.84(10.88)$ & $26.00(0.020)$ & $6.68 * *$ \\
\hline Coarse sand (CS) & $38.0(4.21)$ & $43.4(0.55)$ & $34.6(1.52)$ & $7.00(0.02)$ & $33.94(9.83)$ & $37.00(0.09)$ & $21.64 * *$ \\
\hline Fine sand (FS) & $10.71(2.75)$ & $12.0(0.71)$ & $11.2(0.45)$ & $5.00(0.01)$ & $10.08(3.78)$ & $8.00(0.029)$ & $5.24 * *$ \\
\hline Silt+clay & $29.29(6.65)$ & $31.4(0.55)$ & $23.2(0.45)$ & $71.83(0.41)$ & $25.14(15.04)$ & $29.0(0.014)$ & $21.02 * *$ \\
\hline $\mathrm{pH}$ & $7.42(0.11)$ & $7.41(0.015)$ & $7.01(0.010)$ & $7.15(0.014)$ & $7.55(0.154)$ & $7.20(0.012)$ & $28.01 * *$ \\
\hline Electrical Conductivity $(\mathrm{EC})(\mathrm{mS} / \mathrm{cm})$ & $0.07(0.037)$ & $0.14(0.005)$ & $0.27(0.004)$ & $0.18(0.013)$ & $0.14(0.053)$ & $0.09(0.011)$ & $16.88^{* * *}$ \\
\hline $\mathrm{Na}$ & $0.024(0.018)$ & $0.04(0.005)$ & $0.10(0.007)$ & $0.04(0.007)$ & $0.03(0.015)$ & $0.01(0.004)$ & $29.05^{* *}$ \\
\hline $\mathrm{K}$ & $0.079(0.091)$ & $0.11(0.005)$ & $0.34(0.007)$ & $0.08(0.014)$ & $0.04(0.044)$ & $0.07(0.006)$ & $31.65^{* *}$ \\
\hline $\mathrm{Ca}$ & $0.35(0.60)$ & $0.57(0.009)$ & $0.57(0.013)$ & $0.61(0.014)$ & $0.63(0.17)$ & $0.46(0.012)$ & $7.34 * *$ \\
\hline (mg//m dry wt.) & $0.45(0.082)$ & $0.20(0.007)$ & $0.48(0.011)$ & $0.17(0.010)$ & $0.18(0.87)$ & $0.17(0.010)$ & $31.92 * *$ \\
\hline $\mathrm{Cl}$ & $0.54(0.13)$ & $0.30(0.009)$ & $0.23(0.007)$ & $0.35(0.007)$ & $0.41(0.06)$ & $0.32(0.009)$ & $15.87 * *$ \\
\hline $\mathrm{HCO}_{3}$ & $0.74(0.23)$ & $0.61(0.008)$ & $0.91(0.008)$ & $0.91(0.01)$ & $0.87(0.18)$ & $1.21(0.012)$ & $8.06^{* *}$ \\
\hline $\mathrm{PO}_{4} \quad$ ( $\mu \mathrm{g} / \mathrm{q} \mathrm{m}$ dry wt. $)$ & $0.74(0.23)$ & $1.10(0.011)$ & $5.91(0.02)$ & $1.73(0.01)$ & $3.66(0.89)$ & $3.35(0.010)$ & $65.96^{* *}$ \\
\hline $\mathrm{SO}_{4}$ & $1.41(0.74)$ & $0.90(0.007)$ & $2.97(0.012)$ & $0.35(0.01)$ & $1.32(0.79)$ & $0.61(0.008)$ & $15.77 * *$ \\
\hline Moisture Content (MC) & $1.02(0.71)$ & $1.01(0.007)$ & $3.84(0.01)$ & $4.41(0.01)$ & $5.23(3.91)$ & $0.65(0.009)$ & $4.97 * *$ \\
\hline Altitude (ALT) (m a.s.l.) & $1085.9(47.86)$ & $1592.4(5.72)$ & $1643.2(34.5)$ & $1743.6(18.05)$ & $1984.4(27.40)$ & $1867(13.8)$ & $971.94 * *$ \\
\hline \multicolumn{8}{|l|}{ Diversity indices } \\
\hline Species richness (SR) & $17.71(2.7)$ & $18.40(4.9)$ & $17.60(4.9)$ & $12.50(4.5)$ & $14.47(3.9)$ & $12.25(3.8)$ & $2.57^{*}$ \\
\hline Shannon-Wiener index $\left(\mathrm{H}^{\prime}\right)$ & $2.80(0.16)$ & $2.82(0.32)$ & $2.78(0.27)$ & $2.39(0.33)$ & $2.56(0.29)$ & $2.37(0.35)$ & $2.78^{*}$ \\
\hline Simpson index $(\mathrm{CD})$ & $0.94(0.009)$ & $0.93(0.02)$ & $0.92(0.01)$ & $0.87(0.03)$ & $0.88(0.03)$ & $0.83(0.06)$ & $9.08^{* *}$ \\
\hline Margalef index (M) & $5.57(0.64)$ & $5.71(1.12)$ & $5.52(1.15)$ & $4.26(1.11)$ & $4.77(0.95)$ & $4.21(0.97)$ & $2.63^{*}$ \\
\hline
\end{tabular}

$* *=p<0.01$ 
Whereas Phlomis aurea, Scrophularia deserti and Verbascum sinaiticum were among the common recorded perennial herbs, annual herbs were very modestly (2 species) recorded. Group F (17 species, 8 significant indicator species) was indicated by Gymnocarpos decandrus and Solanum sinaicum. The shrub layer included 6 species (Deverra triradiata, Ballota undulata, Gymnocarpos decandrus, Bufonia multiceps, Polygala sinaica and Solanum sinaicum) and the herb layer composed of two perennial herbs (Galium Sinaicum and Centaurea sinaica). The tree layer was absent, and shrubs were the dominant (12 species) growth form. Soils of this group were the driest (lowest moisture content), and lower contents of most examined nutrients.

Ordination and vegetation-environment correlations

The NMDS ordination was able to distinguish the different vegetation belts along the altitudinal gradient. All six cluster groups (A-F) were separated clearly on the first and second axes (Fig. 4). The final stress was 17.8 , and produced significant result in the Monte Carlo test $(p=0.02)$. More than $70 \%$ of the variation in the dataset was explained by the three NMS axes with $61.7 \%$ explained by the first two axes. Axis 2 explained more of the variability $(46.2 \%)$ than axis $1(15.5 \%)$. Pairwise comparisons between pairs of axes, expressed as $\%$ orthogonality, revealed very high values (Ax1 vs. $\mathrm{Ax} 2=98.7 \%, \mathrm{Ax} 1$ vs. $\mathrm{Ax} 3=98.9 \%, \mathrm{Ax} 2$ vs. $\mathrm{Ax} 3=$ $86.1 \%$ ). This indicated that they were statistically independent. Along axis 1, the sampling plots of cluster groups occur in lower elevations were grouped in the negative side whereas those of higher elevations were grouped in the positive side. Significance correlations ( $p$ $<0.01$ ) of environmental variables with the first NMDS axis were fine sand, electrical conductivity, sodium and altitude, whereas Axis 2 was highly correlated with fine sediments (silt and clay), electrical conductivity and sodium (Table 4).

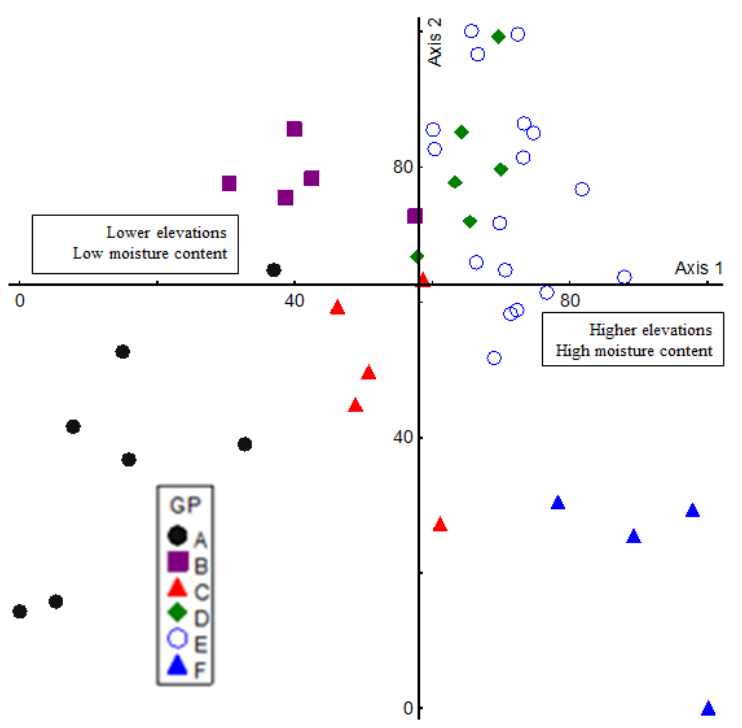

Figure (4): Diagram of NMDS ordination analysis along axes 1 and 2, showing the positions of separated cluster groups (A-F).
The direct correlations between the examined environmental variables and plant species composition were presented in the CCA triplot (Fig. 5). The Monte Carlo permutation test for the first canonical axis was highly significant $(p=0.002)$. The species-environment correlations were high for the three axes explaining $66.8 \%$ of the cumulative variance. From the intra-set correlations of the environmental variables (Table 3), it can be inferred that CCA axis 1 was highly positively correlated $(r=0.635)$ with $\mathrm{Mg}$ and highly negatively correlated with altitude ( $r=-0.959)$. Thus, axis 1 can be identified as $\mathrm{Mg}$-altitude gradient. Axis 2 was highly positively correlated $(r=0.669)$ with chlorides and highly negatively correlated with sodium ( $r=-0.612)$. Thus, axis 2 can be identified as $\mathrm{Cl}-\mathrm{Na}$ gradient. Whiles plots of Group A (lowest altitude; <1500 m a.s.l.) occupied the positive end of CCA axis 1 (Fig. 5) was affected by $\mathrm{Cl}$ and $\mathrm{Mg}$, plots of Groups $\mathrm{E}$ and $\mathrm{F}$ (higher altitudes (1900m and above) occupied the negative end were affected by altitude, bicarbonates, phosphates, calcium and moisture contents of the soil. Groups B and $\mathrm{C}$ of the middle elevations (1600-1800m) occupied intermediate position along Axis 1 , and mainly affected by sodium, potassium and electrical conductivity. Plots of Group D (1700-1800 m a.s.l.) were affected by soil moisture content.

Table (3): Inter-set correlation of CCA analysis for the environmental variables, together with eigenvalues and species-environment relations

\begin{tabular}{|c|c|c|c|}
\hline \multirow{2}{*}{$\begin{array}{l}\text { Environmental } \\
\text { variables }\end{array}$} & \multicolumn{3}{|c|}{ CCA axes } \\
\hline & 1 & 2 & 3 \\
\hline Eigenvalues & 0.607 & 0.299 & 0.239 \\
\hline $\begin{array}{l}\text { Species-environment } \\
\text { correlations }\end{array}$ & 0.985 & 0.945 & 0.930 \\
\hline $\begin{array}{l}\text { Cumulative } \% \text { species } \\
\text { variance of species- } \\
\text { environment relations }\end{array}$ & 35.4 & 52.8 & 66.8 \\
\hline $\mathrm{pH}$ & 0.001 & 0.321 & 0.174 \\
\hline $\begin{array}{l}\text { Electrical conductivity } \\
\text { (EC) }\end{array}$ & -0.208 & $-0.507^{* *}$ & $0.151 *$ \\
\hline $\mathrm{Na}$ & -0.067 & $-0.612 * *$ & $0.169 * *$ \\
\hline $\mathrm{K}$ & 0.054 & $-0.434 *$ & $0.129 *$ \\
\hline $\mathrm{Ca}$ & $0.571 * *$ & -0.314 & 0.167 \\
\hline $\mathrm{Mg}$ & $0.635 * *$ & -0.057 & -0.207 \\
\hline $\mathrm{Cl}$ & $0.445 * *$ & $0.669 * *$ & 0.4005 \\
\hline $\mathrm{HCO}_{3}$ & $0.446^{* * *}$ & $0.392 *$ & -0.306 \\
\hline $\mathrm{PO}_{4}$ & $\stackrel{-}{-}$ & -0.062 & -0.058 \\
\hline $\mathrm{SO}_{4}$ & 0.012 & 0.088 & 0.129 \\
\hline $\begin{array}{l}\text { Moisture Content } \\
\text { (MC) }\end{array}$ & $0.427 * *$ & -0.065 & 0.197 \\
\hline Altitude (ALT) & $\begin{array}{c}- \\
0.959 * * \\
\end{array}$ & -0.003 & 0.131 \\
\hline
\end{tabular}

\section{Species diversity}

The estimated diversity indices showed significant variations among the separated cluster group (Table 2). Generally, the highest values of the four indices were recorded at ca. 1500-1700m. CCA axis 1 was significantly correlated to the measured diversity indices, while CCA axis 2 was only correlated with Simpson index 
(Table 5). The effects of environmental variables on the species diversity indices showed that altitude, coarse and fine sand fractions, magnesium and bicarbonates had significant correlations, while the others were not correlated. Along the elevation gradient, species richness (SR) reached its maximum peak between 1500 and $1700 \mathrm{~m}$, and lowest peak in 1700-1800m (Fig. 6). Above $1500 \mathrm{~m}$ a.s.l., species richness decreased more or less monotonically toward the $1800 \mathrm{~m}$ a.s.l. The highest beta diversity $\left(\beta_{T}\right)$ was found in the lowest $(\mathrm{L} 1,<1500 \mathrm{~m})$ and higher levels (L6; >1900m; Fig. 6), and the lowest values occurred in between 1600-1700 m a.s.l.

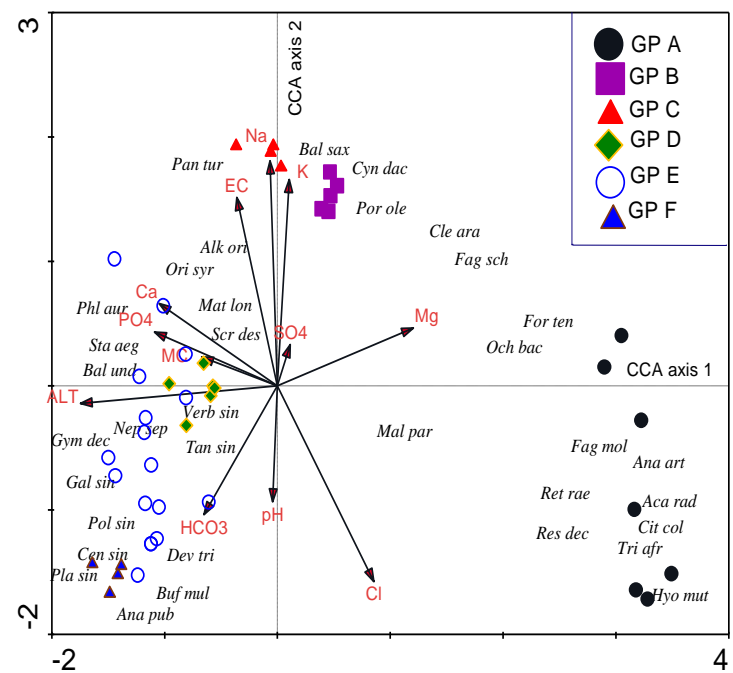

Figure (5): CCA ordination triplot of axes 1 and 2 showing the distribution of 44 sampling plots within their cluster groups (A-F), indicator species and the examined environmantal variables $(\mathrm{MC}=$ Moisture Content, $\mathrm{EC}=$ Electrical Con-ductivity, ALT=Altitude). For species abbreviations, see appendix (2)

Table (4): Spearman rank correlations $(r)$ of environmental variables with the NMDS ordination axes as presented in Fig (4).

\begin{tabular}{|c|c|c|}
\hline \multirow{3}{*}{ Environmental variables } & \multicolumn{2}{|c|}{ NMDS-Axes } \\
\hline & 1 & 2 \\
\hline & $r$ & $R$ \\
\hline Gravel & $-0.142 *$ & $0.191 *$ \\
\hline Coarse sand (CS) & $-0.204^{*}$ & -0.325 \\
\hline Fine sand (FS) & $0.078 * *$ & -0.324 \\
\hline Silt + clay & $0.210^{*}$ & $0.044 * *$ \\
\hline $\mathrm{pH}$ & $0.115^{*}$ & $-0.125^{*}$ \\
\hline Electrical conductivity (EC) & $-0.010 * *$ & $0.058 * *$ \\
\hline $\mathrm{Na}$ & $0.030^{* *}$ & $-0.064 * *$ \\
\hline $\mathrm{K}$ & $-0.200^{*}$ & $0.026^{*}$ \\
\hline $\mathrm{Ca}$ & $0.198 *$ & 0.400 \\
\hline $\mathrm{Mg}$ & $-0.199 *$ & -0.614 \\
\hline $\mathrm{Cl}$ & $-0.104 *$ & -0.342 \\
\hline $\mathrm{HCO}_{3}$ & -0.372 & 0.524 \\
\hline $\mathrm{PO}_{4}$ & -0.261 & 0.441 \\
\hline $\mathrm{SO}_{4}$ & -0.434 & $-0.114^{*}$ \\
\hline Altitude (ALT) & $0.034 * *$ & 0.802 \\
\hline Moisture content (MC) & $0.175^{*}$ & 0.308 \\
\hline
\end{tabular}

Significant correlations:

$*=p<0.05$

$* *=p<0.01$.

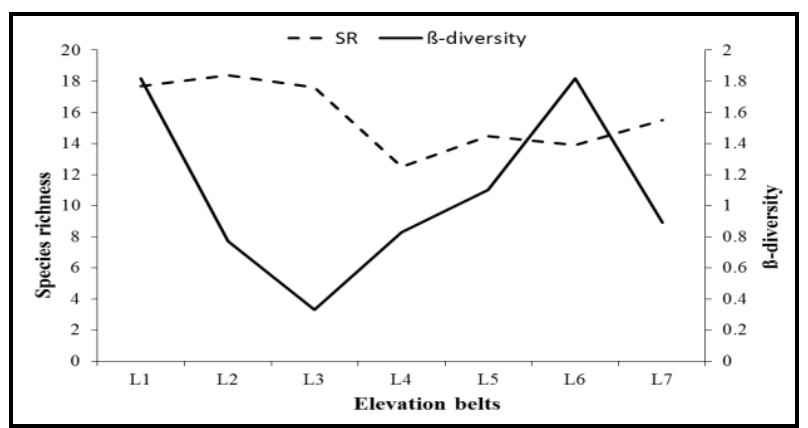

Figure (6): Variations of species richness and beta diversity index along elevation belts (L1-L7). L=>1500 m, L2= $1500-1600 \mathrm{~m}, \quad \mathrm{~L} 3=1600-1700 \mathrm{~m}, \quad \mathrm{~L} 4=1700-1800 \mathrm{~m}, \quad \mathrm{~L} 5=$ $1800-1900 \mathrm{~m}, \mathrm{~L} 6=1900-2000 \mathrm{~m}, \mathrm{~L} 7=<2000 \mathrm{~m}$.

Table (5): Probability values $(p)$ of Spearman rank correlations between diversity indices and scores of 44 sample plots along the first two axes of CCA, and the environmental variables.

\begin{tabular}{|c|c|c|c|c|}
\hline & \multicolumn{2}{|c|}{ Diversity indices } & \multirow[b]{2}{*}{ SR } & \multirow[b]{2}{*}{ Margalef } \\
\hline & $\mathbf{H}^{\prime}$ & Simpson & & \\
\hline \multicolumn{5}{|l|}{ CCA axes } \\
\hline Axis 1 & $0.011 *$ & $0.001 * *$ & $0.018 *$ & $0.016^{*}$ \\
\hline Axis 2 & 0.092 & $0.022 *$ & 0.057 & 0.063 \\
\hline \multicolumn{5}{|c|}{ Environmental variables } \\
\hline ALT & $0.027 *$ & $0.001 * *$ & $0.029 *$ & $0.028 *$ \\
\hline Gravels & 0.203 & 0.035 & 0.210 & 0.207 \\
\hline $\mathrm{CS}$ & $0.002 * *$ & $0.010 *$ & $0.002 * *$ & $0.002 * *$ \\
\hline FS & $0.010 *$ & $0.008 * *$ & $0.015 *$ & $0.014^{*}$ \\
\hline Silt + clay & 0.071 & 0.312 & 0.086 & 0.082 \\
\hline $\mathrm{pH}$ & 0.520 & 0.934 & 0.602 & 0.581 \\
\hline $\mathrm{EC}$ & 0.750 & 0.342 & 0.774 & 0.772 \\
\hline $\mathrm{Na}$ & 0.480 & 0.139 & 0.419 & 0.433 \\
\hline $\mathrm{K}$ & 0.267 & 0.069 & 0.269 & 0.269 \\
\hline $\mathrm{Ca}$ & 0.072 & $0.037^{*}$ & 0.085 & 0.081 \\
\hline $\mathrm{Mg}$ & $0.004 * *$ & $0.001 * *$ & $0.007 * *$ & $0.006 * *$ \\
\hline $\mathrm{Cl}$ & 0.843 & 0.552 & 0.968 & 0.989 \\
\hline $\mathrm{HCO}_{3}$ & $0.002 * *$ & $0.001 * *$ & $0.003 * *$ & $0.003 * *$ \\
\hline $\mathrm{PO}_{4}$ & 0.936 & 0.354 & 0.965 & 0.961 \\
\hline $\mathrm{SO}_{4}$ & 0.237 & 0.212 & 0.303 & 0.288 \\
\hline $\mathrm{MC}$ & 0.839 & 0.535 & 0.807 & 0.813 \\
\hline
\end{tabular}

\section{DISCUSSION}

\section{Floristic relations and growth form patterns}

The total of 81 species (including a bryophyte) constituted the flora of Jabal Musa representing 69 genera and 32 families, which is certainly not final. More thorough field investigations are recommended and would probably add more species as Abd El-Wahab et al. (2006) recorded 114 species between 1990 and 2006 from this area. Asteraceae, Zygophyllaceae, Fabaceae and Lamiaceae characterized the flora of South Sinai which includes many endemic species (Moustafa and Zaghloul 1996, Hatim et al. 2016). This study also confirmed the dominance of Asteraceae, Lamiaceae and Zygophyllaceae as the most represented families which contributed collectively $35.4 \%$ of the total flora. These families represent the most common in the Mediterranean North African flora (Quézel, 1978). The dominance of Asteraceae in all elevation belts in this study may be attributed to their high seed dispersal capacity 
and wide ecological range (Dvorský et al., 2011; Alsherif and Fadl, 2016).

The S/G ratio of Jabal Musa was 1.14 (81 species/69 genera) whereas for the whole mountainous area of South Sinai was 1.70 (472 species/277 genus) and for Gebel Elba was 1.44 (179 species/124 genus). Therefore, the taxonomic diversity was higher in Jabal Musa than in other diverse areas of Egypt. According to Boulos (2009), nine endemic species (Centaurea scoparia, Phlomis aurea, Asclepias sinaica, Nepeta septemcrenata, Polygala sinaica, Anarrhinum pubescens, Origanum syriacum, Thymus decussatus and Caralluma Sinaica) were recorded in this investigation and distributed along the elevational gradient.

Analysis of the growth forms does not show a remarkable trend in Jabal Musa. However, our results revealed that shrubs were the most abundant growth form $(53.09 \%)$ over the 7 elevation belts, followed by herbs $(26 \%)$ and trees were the rarest. This rarity of trees was also reported by Moustafa and Zaghloul (1996) who recorded Crataegus sinaica and Ficus pseudosycomorus at high elevations, and Acacia tortilis subsp. raddiana at low elevations.

It was found that shrubs decreased in their numbers from low altitudes (>1500 m a.s.l.) to high altitudes (1800-1900 $\mathrm{m}$ a.s.1.) and then reached another maximum between 1900-2000 m a.s.1.). This pattern was partly in line with that reported by Dickore and Nüsser (2000) in Nanga Parbat (NW Himalaya, Pakistan). Moustafa and Zaghloul (1996) reported a similar pattern of life form distribution in montane Saint Katherine area of South Sinai. The present study confirmed that tree line was between 1700 and $1800 \mathrm{~m}$ a.s.l., and ceased in the higher elevations. Such trend was consistent with Hoffman and Hoffman (1982) in Chile, and with Klimeš (2003) in E Ladakh (NW Himalayas). A general pattern of declining the numbers of shrubs, perennial and annual herbs from 1500 and $1900 \mathrm{~m}$ a.s.l. was observed. A combined set of ecological parameters may be responsible for this observed pattern (Lomolino 2001). The high percentages of perennials (43 shrubs; 42\%, 21 perennial herbs; $26 \%$ ) may be relate to their ability to resist the drought and salinity.

The short-lived growth form of annuals is an advantage in arid and semi-arid zones. In this study most annuals occur from (1500-1800 $\mathrm{m}$ a.s.l), while their number decreases towards higher altitudes. Temperatures and length of growing season at lower elevations were adequate but soil moisture was not readily available. This may explain the dominance of annual herbs at lower altitudes. Also the predominance of annuals at low altitudes partly can be explained by soil disturbance, which makes a suitable place for ruderals at this belt. A different pattern of life form distribution along altitudinal gradient in which therophytes (annuals) was dominant, followed by phanerophytes and/or chamaephytes was indicated by Abd El-Ghani (1998) in the Eastern Desert of Egypt and Arshad et al. (2008) in the Cholistan desert of Pakistan.

\section{Vegetation belts and floristic gradient}

The NMDS results showed that altitude reflected changes of water availability and soil properties, which defined the classified vegetation belts. Apart from higher elevations (1900->2000 m a.s.l.) which exhibited higher degrees of similarities in their species compositions, while low similarities were indicated between the floristic compositions in the other studied belts. Consequently, the floristic compositions of the elevation gradient in this study were clearly separated and identified as individual vegetation belts. The adverse topographical and ecological conditions that prevail on Jabal Musa were reflected in the lower number of recorded species (maximum 47). These conditions were reported in similar desert habitats (Ward et al., 1993). The rocky habitats of this region permit the growth of species adapted to root penetration, shallow soils and low water content.

Among the dominant species in the study area, Acacia tortilis subsp. raddiana, Retama raetam, Ochradenus baccatus, Anabasis articulata, Fagonia mollis, Trichodesma africanum and Forsskaolea tenacissima showed preference towards lower altitudes $(<1500-1600$ $\mathrm{m}$ a.s.l.) indicating arid dry conditions of desert vegetation. Higher up, Anarrhinum pubescens, Ballota undulata, Plantago sinaica, Polygala sinaica and Bufonia multiceps tend to be associated with higher elevations (1800-2000 m a.s.1.) indicating more humid conditions as they cannot tolerate harsh drought conditions. In comparable, the Jabal Katherine Mountain supported mainly the steppe vegetation dominated by Artemisia inculta, Tanacetum santolinoides and Gymnocarpos decandrum at the higher levels. Low elevations are mostly dominated by Artemisia inculta associated with some other species such as Zilla spinosa and Fagonia mollis on the stony alluvium of ridge habitats (Moustafa and Zaghoul, 1996).

Such variations in floristic composition along altitudinal gradient were reported in other studies (Abd El-Ghani, 1997). The middle elevation belts (1600-1800 $\mathrm{m}$ a.s.1.) harbour some endemic and threated species such as Phlomis aurea, Origanum syriacum, Tanacetum sinaicum and Nepeta septemcrenata that grow in rock cracks and crevices where most nutrient-rich soils were best developed. Therefore, it can be suggested that lower elevation belts can be inferred as the woody species belts that represent a transitional zone (ecotone) between the desert vegetation in the wadis of southern Sinai and the montane vegetation on Jabal Musa.

\section{Vegetation groups along environmental gradients}

Khan et al. (2011) indicated the difficulty of drawing a sharp line in any mountain ecosystem, as rapid micro climatic and edaphic variations overlap each other due to the number of driving agencies and historical perspectives. On the basis of differences in floristic composition, six main vegetation cluster groups were separated. The multi-response permutation procedure (MRPP) showed significant differences between these groups in the environmental matrix, and the pairwise comparisons also revealed significant differences. It can be suggested, therefore, that these are discrete communities with distinct species assemblages. This was also illustrated by the NMDS ordination, which indicated the segregation of the 6 vegetation groups along an elev- 
ation gradient. The six vegetation groups were distributed along the first axis of NMDS ordination. The cluster groups (A): Retama raetam-Anabasis articulataCitrullus colocynthis ( $<1500 \mathrm{~m}$ a.s.1.), (B): Cleome arabica-Matthiola longipetalai (1500-1600 m a.s.l.) and (C): Panicum turgidum-Portulaca oleracea (1600-1700 $\mathrm{m}$ a.s.l.) inhabited the lower elevations with dry soil occupied the negative side The groups of higher elevations (D): Nepeta septemcrenata-Pulicaria incisa (1700-1800 m a.s.1.), (E): Plantago sinaica-Anarrhinum pubescens (above $1900 \mathrm{~m}$ a.s.l) and (F): Gymnocarpos decandrus-Solanum sinaicum (1800-1900 m a.s.l) with wetter soil content occupied the positive side.

In the montane Saint Katherine area, including Jabal Musa area, Moustafa and Zaghloul (1996) identified six main plant communities: (1) Tanacetum santolinoides, (2) Artemisia inculta, (3) Artemisia inculta-Atraphaxis spinosa, (4) Artemisia inculta-Lycium shawii, (5) Artemisia inculta-Fagonia mollis, and (6) Artemisia inculta-Achillea fragrantissima. In terms of classification, none of our vegetation groups were comparable to the aforementioned groups or those reported by Shaltout et al. (2015). A possible explanation for this controversy is that the present study represents the first detailed one dealing with the vegetation on Jabal Musa of south Sinai. However, some associated species in the previous works were included, to a certain extent, in our groups but not to a definite one, e.g., Seriphidium herba-alba, Zilla spinosa, Fagonia mollis, Stachys aegyptiaca, Lycium shawii, Artemisia judaica and Onopordum ambiguum in groups at lower elevations, and Deverra triradiata, Galium sinaicum, Anarrhinum pubescens, Bufonia multiceps, Nepeta septemcrenata, Plantago sinaica, Thymus decussatus and Chiliadenus montanus in groups at higher elevations. Both NMDS and CCA analyses confirmed the significance of eleva-tion and most of the examined soil variables $(p<0.01$; Table 2$)$, controlling the distribution of plant commu-nities on Jabal Musa. According to Moustafa and Zaghloul (1996), the nature of the soil surface in the form of boulders and stones, and cobbles and surface gravel is one of the most important factors controlling moisture availability and subsequently the distribution of plant communities in Saint Katherine mountainous area. Also, our results were in concurrence with other relevant studies on the mountains of arid and semi-arid regions of the globe (Hegazy et al., 2008; Muenchow et al., 2013).

\section{Species diversity along elevation gradient}

According to Rahbek (1995), the general major patterns that found to determine the relationship between species richness and altitude are: hump-shaped (mid-altitude peak) (e.g., Lomolino, 2001; Grytnes and Vetaas, 2002); monotonically decreasing species richness with increasing altitude (Ghazanfar, 1991); and both monotonic and hump-shaped relationships (Grytnes, 2003). The variation in patterns has been reviewed by Rahbek (1995), and suggested that the differences between studies could partly be explained by the samp- ling design and that the influence of area has often been ignored. Along Jabal Musa, the trend in species diversity with altitude is unclear; however it does not decreese over the whole altitude range and is relatively high at the upper elevations. A possible explanation can be attributed to the fluctuation of habitats occurred at high elevations more than in the lower. According to Mostafa and Klopatek 1995), these habitats included terraces, slopes, crevices and gorges; each characterized by a variety of species which may increase the species richness at higher altitudes. This finding was also consistent with those of Wang (2002) and Zhang and Chen (2004) who found that this pattern is the most common one in a variety of ecosystems.

Beta diversity defined as the extent of species replacement or biotic change along environmental gradients (Whittaker, 1972) decreases with altitude. This trend suggests that species composition is rather variable at lower elevations, while at higher elevations it tends to become more uniform. Wang et al. (2002) pointed out that complicated habitats as well as intensive human disturbance would give rise to higher species turnover along an elevation gradient. Our results revealed that $\beta$ diversity values peaked at lower elevation as well as higher elevation. These two peaks appeared to correspond to vegetation extremes from arid lowland with warm dry climate to semiarid montane with cold and humid habitats. These changes may be also interpreted based on the human activity. This long experienced human activity being an available source of wood for fuel and heating. Moustafa and Klopatek (1995) documented that more than 61 rare species in south Sinai are threatened owing to overcutting and livestock grazing.

\section{General conclusions}

As no demarcation line existed between the plant communities on Jabal Musa, it was possible in the present study to identify six significantly different vegetation groups distributed along an altitudinal gradient (<1500 m a.sl - >2000 m a.s.1.). Two main vegetation units can be recognized: low ground and high ground. The indicator species analysis (ISA) revealed that the identified groups were partly irrelevant to other recognized groups from the area. Neither monotonic nor hump-shaped relationships of species richness with altitude were indicated. Yet, in certain part of the gradient, the plant species diversity decreased significantly with altitude. Fluctuations of habitats on Jabal Musa may explain the increased species richness in higher levels. Statistical analyses proved the significant variations between the environmental factors (including altitude) and the vegetation composition. Along the elevation gradient, the tree line was delimited between 1700 and $1800 \mathrm{~m}$ a.s.1., while shrubs and perennial herbs were the dominant growth forms. This detailed study contributed to further our knowledge of the vegetation composition in the region. Future work should be conducted on the effect of other biotic and abiotic variations in species diversity. 


\section{REFERENCES}

ABD EL-GHANI, M.M. 1997. Vegetation analysis and species diversity along an altitudinal gradient in the central Hijaz mountains of Saudi Arabia. Arab Gulf J Sci Res 15(2): 399-414.

ABD EL-GHANI, M.M. 1998. Environmental correlates of species distribution in arid desert ecosystems of eastern Egypt. J Arid Environ 38: 297-313.

ABD EL-GHANI, M.M., AND K. ABDEL KHALIK. 2006. Floristic Diversity and Phytogeography of the Gebel Elba National Park, South-East Egypt. Turk J Bot 30: 121-136.

ABD EL-GHANI, M.M., AND W. AMER. 2003. Soilvegetation relationships in a coastal desert plain of southern Sinai, Egypt. J Arid Environ 55: 607-628.

ABD EL-WAHAB, R.H., M.S. ZAGHLOUL AND A.A. MOUSTAFA. 2006. Vegetation and environment of Gebel Serbal, South Sinai, Egypt. Catrina 1(2): 9-20.

ALSHERIF, E.A., AND M.A. FADL. 2016. Floristic study of the Al-Shafa Highlands in Taif, western Saudi Arabia. Flora 225: 20-29

ARSHAD, M, A. UL-HUSSAN, M. ASHRAF, S. NOUREEN, AND M. MOAZZAM. 2008. Edaphic factors and distribution of vegetation in the Cholistan desert, Pakistan. Pak J Bot 40(5): 19231931.

AYYAD, M.A., A.M. FAKHRY, AND A.A. MOUSTAFA. 2000. Salt marsh vegetation of the western Mediterranean desert of Egypt. Vegetatio 49: 3-19.

BENHOUHOU, S.S., T.C.D. DARGIE, AND O.L. GILBERT. 2003. Vegetation associations in the Ougarta Mountains and dayas of the Guir hamada, Algerian Sahara. J Arid Environ 54(4): 739-753.

BOULOS, L. 1995. Flora of Egypt. Checklist. Al Hadara Publishing. Cairo, Egypt.

BOULOS, L. 1999. Flora of Egypt. Vol. 1. AzollaceaeOxalidaceae. Cairo, Egypt: Al Hadara Publishing.

BOULOS, L. 2000. Flora of Egypt. Vol. 2. Geraniaceae-Boraginaceae. Cairo, Egypt: Al Hadara Publishing.

BOULOS, L. 2002. Flora of Egypt. Vol. 3. Verbenaceae-Compositae. Cairo, Egypt: Al Hadara Publishing.

BOULOS, L. (2009). Flora of Egypt. Check list Revised annotated edition. Cairo, Egypt: Al Hadara Publishing.

DANIN, A. 1978. Plant species diversity and ecological districts of the Sinai desert. Vegetatio 36: 83-93.

DICKORÉ, W.B., AND M. NÜSSER. 2000. Flora of Nanga Parbat (NW Himalaya, Pakistan): anannotated inventory of vascular plants with remarks on vegetation dynamics. Englera 19: 1-253.

DUFRENE, M., AND P. LEGENDRE. 1997. Species assemb-lages and indicator species: the need for flexible asymmetrical approach. Ecol Monogr 67: 345-366.

DVORSKÝ, M., J. DOLEŽAL, F. DE BELLO, J. KLIMEŠOVÁ, L. KLIMEŠ. 2011. Vegetation of
East Ladakh: species and growth form composition along environmental gradients in Western Himalayas. Appl Veg Sci 14: 132-147.

GHAZANFAR, S.A. 1991. Vegetation structure and phytogeography of Jabal Shams, an arid mountain in Oman. J Biogeogr 18: 299-309.

GRYTNES, J.A. 2003. Species-richness patterns of vascular plants along seven altitudinal transects in Norway. Ecography 26: 291-300.

GRYTNES, J.A., AND O.R. VETAAS. 2002. Species richness and altitude: a comparison between simulation models and interpolated plant species richness along the Himalayan altitude gradient, Nepal. Am Nat 159: 294-304.

HATIM, M.Z., K.H. SHALTOUT, J.H. SCHAMINE, H.F. EL-KADY, J. JANSSEN AND M.A. ELSHEIKH 2016. VegEgypt ecoinformatics: contribution to Sinai flora and vegetation. Rend Fis Acc Lincei 27: 383-399.

HAZEN, A. 1989. On determination of chloride in water. Am J Chem 2: 409-425.

HEGAZY, A.K., L. BOULOS, H.F. KABIEL, O.S. SHARASHY. 2011). Vegetation and species altitudinal distribution in Al-Jabal Al-Akhdar landscape, Libya. Pak J Bot 43(4): 1885-1898.

HEGAZY, A.K., O. HAMMOUDA, J. LOVETTDOUST, N.H. GOMAA. 2008. Population dynamics of Moringa peregrina along altitudinal gradient in the northwestern sector of the Red Sea. J Arid Environ 72: 1537-1551.

HENDERSON, P.A., AND R.M.H. SEABY. 1998. Species Diversity and Richness, version 2.3. Lymington, UK: Pisces Conservation Ltd.

HOFFMANN, A.J., AND A.E. HOFFMANN. 1982. Altitudinal ranges of phanerophytes and chamaephytes in central Chile. Vegetation 48: 151-163.

JAFARI, M., M. BINIAZ, E. JANFAZA, M.J. NEMATOLAHI, AND M. KARIMPOUR REYHAN. 2013. Relationship between soil characteristics and vegetation types in Damghan. Desert 17: 129-135.

KHAN, S.M., D. HARPER, S. PAGE, AND H. AHMAD. 2011. Species and community diversity of vascular flora along environmental gradient in Naran Valley: A multivariate approach through indicator species analysis. Pak J Bot 43(5): 2337-2346.

KLIMEŠ, L. 2003. Life-forms and clonality of vascular plants along an altitudinal gradient in E Ladakh (NW Himalayas). Basic Appl Ecol 4: 317-328.

KÖRNER, C. 2000. Why are there global gradients in species richness? Mountains might hold the answer. Trends Ecol Evol 15: 513-514.

LOMOLINO, M.V. 2001. Elevation gradients of species-richness, historical and prospective views. Global Ecol Biogeogr 10: 3-13.

MAFF, (MINISTRY OF AGRICULTURE, FISHERIES AND FOOD). 1986. The Analysis of Agricultural Materials. London: HMSO.

MAGURRAN, A.E. (2004). Measuring biological diversity. Oxford, UK: Wiley-Blackwell Publishing,

MCCUNE, B., AND J.B. GRACE. (2002). Analysis of Ecological Communities. Ordination of plant 
communities. The Hague: MJM Press.

MCCUNE, B., AND M.J. MEFFORD. 1999. PCORD for windows. Multivariate Analysis of Ecological Data. Version 4.14. User's Guide. Oregon, USA: MjM Software.

MOUSTAFA, A.A., AND J.M. KLOPATEK. 1995. Vegetation and landforms of the Saint Catherine area, southern Sinai, Egypt. J Arid Environ 30: 385395.

MOUSTAFA, A.A., AND M.S. ZAGHLOUL. 1996. Environment and vegetation in the montane Saint Catherine area, South Sinai, Egypt. J Arid Environ 34: 331-349.

MUENCHOW, J., S. HAUENSTEIN, A. BRÄUNING, R. BÄUMLER, E. FRANK RODRÍGUEZ AND H VON WEHRDEN. 2013. Soil texture and altitude, respectively, largely determine the floristic gradient of the most diverse fog oasis in the Peruvian desert. J Trop Ecol 29: 427-438.

PECK, J.E. 2010. Multivariate Analysis for Community Ecologists: Step-by-Step using PC-ORD. Oregon, USA: MjM Software Design.

QUÉZEL, P. 1978. Analysis of the flora of Mediterranean and Saharan Africa. Ann Miss Bot Gard 65: 479-534.

RAHBEK, C. 1995. The elevation gradient of species richness: a uniform pattern? Ecography 18: 200-205.

SALAMA, F., M. ABD EL-GHANI, M. GADALLAH, S. EL-NAGGAR, AND A. AMRO. 2015. Diversity and responses of plant functional groups to soil variables in the arid desert landscape of southern Egypt. J Biodiv Ecol Sci 5(1): 24-39.

SAID, R. 1962. The Geology of Egypt. Amsterdam: Elsevier.

SHALTOUT, K.H., A.A. DALIA, AND H.A. SHABANA. 2015. Population structure and dynamics of the endemic species Phlomis aurea Decne in different habitats in southern Sinai Peninsula, Egypt. Global Ecol Conserv 4: 505-515.
TÄCKHOLM, V. 1974 Students' Flora of Egypt. $2^{\text {nd }}$ ed. Cairo, Egypt: Cairo University Press.

TER BRAAK, C.J.F. 1990. Update notes: CANOCO version 3.1. Wageningen: Agricultural Mathematics Group.

TER BRAAK, C.J.F., AND P. ŠMILAUER. 2002. CANOCO (version 4.5). Reference manual and Canodraw for Windows. User's Guide: software form canonical community ordination. Ithaca: Microcomputer Power.

VERMA, B.C., K. SWAMINATHAN, K.C. SUD. 1977. An improved turbidimetric procedure for determination of sulphate in plants and soils. Talanta 24: 49-50.

VETAAS, O.R. 1992. Gradients in field-layer vegetation on an arid misty mountain plateau in the Sudan. J Veg Sci 3: 527-534.

WANG, G., G. ZHOU, L. YANG, AND Z. LI. 2002. Distribution, species diversity and life-form spectra of plant communities along an altitudinal gradient in the northern slopes of Qilianshan Mountains, Gansu, China. Plant Ecol 165: 169-181.

WARD, D., L. OLSVIG-WHITTAKER, M. LAWES. 1993. Vegetation environment relationship in a Negev Desert erosion Cirque. J Veg Sci 4: 83-94.

WHITTAKER, R.H. 1972. Evolution and measure-ment of species diversity. Taxon 21: 213-251.

WILSON, M.V., AND A. SHMIDA. 1984. Measuring beta diversity with presence absence data. J Ecol 72: 1055-1064.

WOODS, J., AND M. MELLON. 1941. Molybdenum Blue Reaction: A Spectrophotometric Study. Ind Eng Chem Anal Ed 13(11): 760-764.

ZHANG, J.T., AND T.G. CHEN. 2004. Variation of plant communities along an elevation gradient in the Guandi Mountains, North China. Comm Ecol 5(2): 227-233.

ZOHARY, M. 1973. Geobotanical Foundations of the Middle East. Vols 1\&2. Stuttgart: Gustav FischerVerlag. 
APPENDIX (1)

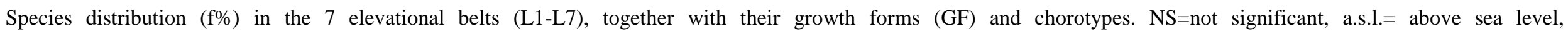
$\mathrm{ME}=$ Mediterranean, SA=Saharo-Arabian, SZ=Sudano-Zambezian, SU=Sudanian, IT=Irano-Turanian. E=Endemic, COSM=Cosmopolitan, PAN=Pantropical.

\begin{tabular}{|c|c|c|c|c|c|c|c|c|c|}
\hline Species & L1 & $\begin{array}{lll}L_{2} \\
500\end{array}$ & $\begin{array}{llll}\mathrm{L3} \\
600\end{array}$ & L4 & L5 & L6 & $\begin{array}{ll}\text { L7 } \\
\end{array}$ & GF & Chorotype \\
\hline & & $\begin{array}{l}1500- \\
1600\end{array}$ & $\begin{array}{l}1600- \\
17700\end{array}$ & $1700-$ & $1800-$ & $1900-$ & $>2000$ & & \\
\hline \multirow{7}{*}{ 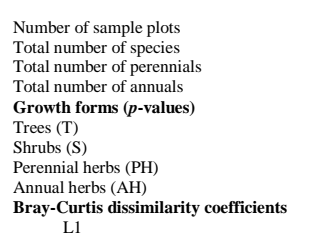 } & 7 & 5 & 5 & 6 & 4 & ${ }_{11} 000$ & 6 & & \\
\hline & 47 & 29 & 26 & 24 & 17 & 36 & 31 & & \\
\hline & ${ }_{9}^{38}$ & ${ }_{4}^{25}$ & ${ }_{3}^{23}$ & ${ }_{5}^{19}$ & ${ }_{2}^{15}$ & $\begin{array}{l}31 \\
5\end{array}$ & ${ }_{2}^{29}$ & & \\
\hline & & NS & NS & NS & NS & NS & & & \\
\hline & 0.0001 & 0.0001 & 0.0001 & 0.0001 & 0.001 & 0.0001 & 0.0001 & & \\
\hline & $\begin{array}{l}0.0004 \\
0.002\end{array}$ & $\begin{array}{l}0.001 \\
\mathrm{NS}\end{array}$ & $\begin{array}{l}\text { NS } \\
\text { NS }\end{array}$ & $\begin{array}{l}\text { NS } \\
0.033\end{array}$ & NS & 0.003 & 0.003 & & \\
\hline & & & & & & & & & \\
\hline${ }_{\mathrm{L} 2}^{\mathrm{LI}}$ & 0.623 & & & & & & & & \\
\hline $\begin{array}{l}\mathrm{L3} \\
\mathrm{L} 4\end{array}$ & $\begin{array}{l}0.706 \\
0.784\end{array}$ & $\begin{array}{l}0.568 \\
0.635\end{array}$ & 0.528 & 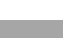 & & & & & \\
\hline $\begin{array}{l}\mathrm{L} 4 \\
\mathrm{~L} 5\end{array}$ & 0.901 & 0.902 & 0.639 & 0.722 & (e & & & & \\
\hline L6 & 0.780 & 0.609 & 0.563 & 0.537 & 0.655 & 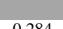 & & & \\
\hline Families with highest numbers of & & & & & & & & & \\
\hline $\begin{array}{l}\text { species } \\
\text { Asteraceae }\end{array}$ & 9 & 5 & 7 & 10 & 5 & & 10 & & \\
\hline $\begin{array}{l}\text { Asseraceac } \\
\text { Lamiaceae }\end{array}$ & 1 & 3 & 6 & 3 & 3 & 7 & 5 & & \\
\hline $\begin{array}{l}\text { Zygophyllaceae } \\
\text { Brassigcaec }\end{array}$ & 5 & 3 & 2 & 2 & 1 & 2 & 1 & & \\
\hline $\begin{array}{l}\text { Brassicacaeae } \\
\text { Scrophulariaceae }\end{array}$ & 4 & 2 & 0 & 0 & 1 & 3 & $\begin{array}{l}3 \\
3\end{array}$ & & \\
\hline $\begin{array}{l}\text { Paaceae } \\
\text { Distribution patterns of species }\end{array}$ & 1 & 1 & 2 & 0 & 0 & 1 & 0 & & \\
\hline $\begin{array}{l}\text { Species recorded in all belts } \\
\text { Seriphidium herba-alba (Asso) Sojak }\end{array}$ & 86 & & 80 & 67 & 20 & 82 & 50 & $\mathrm{~s}$ & \\
\hline $\begin{array}{l}\text { Zilla spinosa ( (L) Prant } \\
\text { Sels }\end{array}$ & 86 & 100 & 80 & 50 & 20 & 73 & 67 & s & $\mathrm{SA}$ \\
\hline 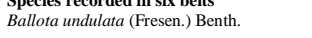 & 0 & 40 & 60 & 83 & 100 & 18 & 50 & $\mathrm{~s}$ & $\mathrm{ME}$ \\
\hline 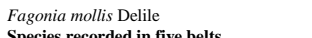 & 57 & 60 & 60 & 50 & 0 & 18 & 17 & $\mathrm{~s}$ & SA, IT \\
\hline Achillea fragrantissima (Forssk.) Sch. & 0 & 60 & 80 & 67 & 0 & 18 & 33 & $\mathrm{~s}$ & $\mathrm{SA}, \mathrm{IT}$ \\
\hline $\begin{array}{l}\text { Bip. } \\
\text { Alkanna orientalis (L.) Boiss. }\end{array}$ & 0 & 100 & 60 & 33 & 0 & 27 & 17 & $s$ & SA, SZ \\
\hline Artemisia judaica $\mathrm{L}$. & 71 & 80 & 60 & 17 & 0 & 0 & 17 & s & $\mathrm{SA}$ \\
\hline $\begin{array}{l}\text { Centuturea scoparaia Sieber ex Spreng. } \\
\text { Peganum harmala. }\end{array}$ & ${ }_{57}^{14}$ & $\begin{array}{l}0 \\
0\end{array}$ & $\begin{array}{l}60 \\
60\end{array}$ & ${ }_{33}^{0}$ & $\begin{array}{l}75 \\
70 \\
50\end{array}$ & ${ }_{9}^{45}$ & $\begin{array}{l}67 \\
0\end{array}$ & ${ }_{\mathrm{PH}}^{\mathrm{S}}$ & ${ }_{\mathrm{ME}, \mathrm{IT}}^{\mathrm{E}}$ \\
\hline $\begin{array}{l}\text { Phomis aurea Decne. } \\
\text { Pons }\end{array}$ & 0 & 80 & 100 & 50 & 0 & 64 & 100 & 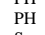 & $\begin{array}{l}\mathrm{M} \text { M, } \\
\mathrm{E}, 11\end{array}$ \\
\hline 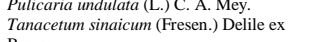 & $\begin{array}{l}144 \\
0\end{array}$ & ${ }_{0}^{60}$ & $\begin{array}{l}0 \\
60\end{array}$ & $\begin{array}{l}50 \\
100\end{array}$ & $\begin{array}{l}0 \\
75\end{array}$ & $\begin{array}{l}45 \\
73\end{array}$ & $\begin{array}{l}50 \\
100\end{array}$ & $\begin{array}{l}\mathrm{s} \\
\mathrm{s}\end{array}$ & 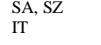 \\
\hline $\begin{array}{l}\text { Bener } \\
\text { Teucrium decaisnei C. Presl }\end{array}$ & 0 & 40 & 80 & 0 & 75 & 73 & 67 & s & $\mathrm{ME}, \mathrm{IT}$ \\
\hline $\begin{array}{l}\text { Verbascum sinaiticum Benth. } \\
\text { Species recorded in four belts }\end{array}$ & 29 & 100 & 0 & 0 & 20 & 64 & 67 & PH & $\mathrm{ME}, \mathrm{IT}$ \\
\hline & 0 & 60 & 80 & 67 & 0 & 0 & 17 & s & $\mathrm{E}$ \\
\hline 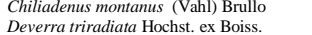 & $\begin{array}{l}0 \\
14\end{array}$ & $\begin{array}{l}0 \\
0\end{array}$ & ${ }_{0}^{60}$ & ${ }_{0}^{67}$ & ${ }_{75}^{0}$ & $\begin{array}{l}82 \\
36\end{array}$ & $\begin{array}{l}50 \\
67\end{array}$ & ${ }_{\mathrm{s}}^{\mathrm{s}}$ & $\mathrm{SE}_{\mathrm{SA}, \mathrm{SZ}}$ \\
\hline $\begin{array}{l}\text { Devereatrfradadata Hochst. ex Boiss } \\
\text { Echinoss spinosus L }\end{array}$ & 43 & 0 & 0 & 17 & & 36 & 50 & PH & $\begin{array}{l}\text { SA, SL } \\
\text { SA, IT }\end{array}$ \\
\hline Galium sinaicum (Delile ex Decne.) & 0 & 0 & 0 & 50 & 75 & 36 & 33 & $\mathrm{PH}$ & $\mathrm{ME}$ \\
\hline $\begin{array}{l}\text { Boiss. } \\
\text { Mathiola longipetala (Vent.) DC. }\end{array}$ & 0 & 100 & 0 & 33 & 0 & 54 & 50 & $\mathrm{AH}$ & $\mathrm{ME}, \mathrm{SA}, \mathrm{IT}$ \\
\hline 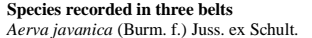 & 14 & & 20 & 0 & 0 & 0 & 0 & s & SA, SZ \\
\hline Centaurea sinaica DC. & ${ }_{0}^{14}$ & 0 & 0 & 0 & 75 & 9 & 50 & AH & $\mathrm{SA}$ \\
\hline Cynodon dactylon (L.) Pers. & 14 & 80 & 80 & 0 & 0 & 0 & 0 & PH & PAN \\
\hline $\begin{array}{l}\text { Gymmocarpos decandrus Forssk. } \\
\text { Jumus acutus } \mathrm{L}\end{array}$ & $\begin{array}{l}0 \\
0\end{array}$ & ${ }_{40}^{0}$ & 40 & $\begin{array}{l}0 \\
0 \\
0\end{array}$ & 100 & ${ }_{36}^{18}$ & ${ }_{50}^{0}$ & sp & ME, SA \\
\hline 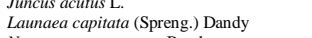 & 0 & ${ }_{0}^{40}$ & 40 & 33 & 50 & 0 & 0 & ${ }_{\mathrm{AH}}^{\mathrm{H}}$ & $\begin{array}{l}\mathrm{MA}, 1 \mathrm{I} \\
\mathrm{SA}, \mathrm{su}\end{array}$ \\
\hline $\begin{array}{l}\text { Nepeta septemcrenata Benth. } \\
\text { phenta }\end{array}$ & 0 & 0 & 0 & 100 & 0 & 27 & 67 & $\mathrm{PH}$ & E \\
\hline $\begin{array}{l}\text { Plantago amplexicaulis Cav. } \\
\text { Polygala sinaica Botsch. }\end{array}$ & $\begin{array}{l}0 \\
0\end{array}$ & $\begin{array}{l}0 \\
0\end{array}$ & ${ }_{0}^{40}$ & ${ }_{0}^{17}$ & ${ }_{75}^{0}$ & ${ }_{18}^{9}$ & ${ }_{33}^{0}$ & ${ }_{\mathrm{S}}^{\mathrm{AH}}$ & $\begin{array}{l}\text { ME, SA, SZ } \\
\text { M }\end{array}$ \\
\hline
\end{tabular}


Vegetation patterns and floristic composition on Jabal Musa

\begin{tabular}{|c|c|c|c|c|c|c|c|c|c|}
\hline $\begin{array}{l}\text { Species } \\
\text { Portulaca }\end{array}$ & L1 & L2 & L3 & $\mathrm{L} 4$ & L5 & L6 & L7 & GF & Chorotype \\
\hline $\begin{array}{l}\text { Portulaca o oleracea L. } \\
\text { Scrophularia deserti Delile }\end{array}$ & ${ }_{0}^{14}$ & $\begin{array}{l}60 \\
60\end{array}$ & 80 & $\begin{array}{l}0 \\
0 \\
0\end{array}$ & $\begin{array}{l}0 \\
0 \\
0\end{array}$ & ${ }_{45}^{0}$ & ${ }_{33}^{0}$ & $\begin{array}{l}\mathrm{AH} \\
\mathrm{PH}\end{array}$ & \\
\hline $\begin{array}{l}\text { Scrophilaria deserti Dedile } \\
\text { Stachys aegyptiaca Pers. }\end{array}$ & $\begin{array}{l}{ }_{0}^{0} \\
0\end{array}$ & ${ }_{0}^{60}$ & 80 & $\begin{array}{l}{ }_{0}^{0} \\
0\end{array}$ & 75 & $\begin{array}{l}45 \\
18\end{array}$ & $0_{0}^{33}$ & $\begin{array}{l}\mathrm{PH} \\
\mathrm{S}\end{array}$ & $\begin{array}{l}\mathrm{SA}, \mathrm{ME} \\
\mathrm{SA}, \mathrm{M}\end{array}$ \\
\hline $\begin{array}{l}\text { Species recordded in tow belts } \\
\text { Anarrhinum pubescens Fresen. }\end{array}$ & 0 & 0 & 0 & 0 & 0 & 27 & 50 & PH & \\
\hline 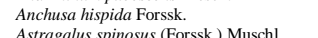 & 14 & $\begin{array}{l}0 \\
0\end{array}$ & $\begin{array}{l}0 \\
0\end{array}$ & 17 & $\begin{array}{l}0 \\
0\end{array}$ & 0 & $\begin{array}{l}0 \\
0\end{array}$ & $\mathrm{AH}_{\mathrm{S}}$ & $\begin{array}{l}\text { SA, IT } \\
\text { SA IT }\end{array}$ \\
\hline $\begin{array}{l}\text { Astragaglus spinosusu( (Forsks.) Muschl. } \\
\text { Bufonia multiceps Decne. }\end{array}$ & ${ }_{0}^{29}$ & $\begin{array}{l}0 \\
0\end{array}$ & $\begin{array}{l}0 \\
0 \\
0\end{array}$ & $\begin{array}{l}0 \\
0 \\
0\end{array}$ & ${ }_{75}^{0}$ & ${ }_{0}^{27}$ & $\begin{array}{l}0 \\
50\end{array}$ & s & $\begin{array}{l}\text { SA, IT } \\
\text { ME }\end{array}$ \\
\hline $\begin{array}{l}\text { Chenopodium murale L. } \\
\text { Cleome arabica L. }\end{array}$ & ${ }_{29}^{29}$ & $\begin{array}{l}40 \\
80\end{array}$ & $\begin{array}{l}0 \\
0\end{array}$ & $\begin{array}{l}0 \\
0\end{array}$ & $\begin{array}{l}0 \\
0\end{array}$ & $\begin{array}{l}0 \\
0\end{array}$ & $\begin{array}{l}0 \\
0\end{array}$ & $\underset{\mathrm{S}}{\mathrm{AH}}$ & COSM \\
\hline $\begin{array}{l}\text { Cleome arabibca L- } \\
\text { Crataegus sinaica Boiss. }\end{array}$ & 0 & $\begin{array}{l}80 \\
0\end{array}$ & $\begin{array}{l}0 \\
0\end{array}$ & 0 & $\begin{array}{l}0 \\
0\end{array}$ & 36 & 17 & s & $\begin{array}{l}\text { SA,II } \\
\text { ME, IT }\end{array}$ \\
\hline Erodium glaucophyllum (L.) L'Her. & 43 & 40 & 0 & 0 & 0 & 0 & 0 & PH & $\begin{array}{l}\mathrm{ME}, \mathrm{TT} \\
\mathrm{COSM}\end{array}$ \\
\hline $\begin{array}{l}\text { Euphorbia helioscopia L. } \mathrm{L} \text {. } \\
\text { Fagoniza arabica L varaca }\end{array}$ & ${ }_{86}^{0}$ & 40 & $\begin{array}{l}0 \\
0\end{array}$ & $\begin{array}{l}0 \\
0\end{array}$ & 0 & 9 & $\begin{array}{l}0 \\
0\end{array}$ & $\mathrm{AH}$ & $\operatorname{cosM}$ \\
\hline $\begin{array}{l}\text { Fagonoia arabicaca L varararabica } \\
\text { Fagonia schimperi C. Presl }\end{array}$ & ${ }_{29}^{80}$ & $\begin{array}{l}40 \\
60\end{array}$ & 0 & $\begin{array}{l}0 \\
0 \\
0\end{array}$ & $\begin{array}{l}0 \\
0\end{array}$ & $\begin{array}{l}0 \\
0 \\
0\end{array}$ & $\begin{array}{l}0 \\
0 \\
0\end{array}$ & $\begin{array}{l}\text { SH } \\
\text { SH }\end{array}$ & $\begin{array}{l}\text { SA } \\
\text { SA }\end{array}$ \\
\hline $\begin{array}{l}\text { Ficus palmata Forssk. } \\
\text { Forstate }\end{array}$ & 0 & 40 & & 0 & 0 & 0 & 0 & $\mathrm{~T}$ & ME \\
\hline 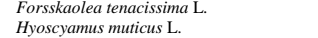 & $\begin{array}{l}43 \\
14\end{array}$ & $\begin{array}{l}60 \\
40\end{array}$ & $\begin{array}{l}0 \\
0 \\
0\end{array}$ & $\begin{array}{l}0 \\
0 \\
0\end{array}$ & & & $\begin{array}{l}0 \\
0 \\
0\end{array}$ & $\begin{array}{l}\mathrm{PH} \\
\mathrm{PH}\end{array}$ & $\begin{array}{l}\text { SA, SZ } \\
\text { SA IT }\end{array}$ \\
\hline $\begin{array}{l}\text { Hossosyamus sutitucu L. } \\
\text { Iphiona scabra DC. }\end{array}$ & 14 & ${ }_{0}^{40}$ & $\begin{array}{l}0 \\
0 \\
0\end{array}$ & $\begin{array}{l}0 \\
0 \\
0\end{array}$ & $\begin{array}{l}0 \\
0\end{array}$ & $\begin{array}{l}0 \\
0\end{array}$ & ${ }_{33}^{0}$ & ${ }_{\mathrm{S}}^{\mathrm{PH}}$ & $\begin{array}{l}\text { SA,IT } \\
\text { SA }\end{array}$ \\
\hline 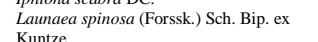 & 29 & 0 & 0 & 0 & 0 & 9 & 0 & s & \\
\hline $\begin{array}{l}\text { Kuntze } \\
\text { Lycium shawii Roem. \& Schult. }\end{array}$ & 43 & 40 & 0 & 0 & 0 & 0 & 0 & s & SA, SZ, IT \\
\hline Malva parviffora $\mathrm{L}$. & 29 & 0 & 0 & 50 & 0 & 0 & 0 & AH & $\mathrm{ME}, \mathrm{IT}$ \\
\hline $\begin{array}{l}\text { Ochradenus baccatus Delile } \\
\text { Onnopordum ambium Fresen }\end{array}$ & $\begin{array}{l}100 \\
0\end{array}$ & $\begin{array}{l}0 \\
40\end{array}$ & $\begin{array}{l}100 \\
0\end{array}$ & 0 & $\begin{array}{l}0 \\
0 \\
0\end{array}$ & $\begin{array}{c}0 \\
0\end{array}$ & $\begin{array}{l}0 \\
0 \\
0\end{array}$ & $\begin{array}{c}\mathrm{s} \\
\mathrm{PH}\end{array}$ & SA \\
\hline 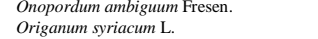 & $\begin{array}{l}0 \\
0 \\
0\end{array}$ & ${ }_{0}^{40}$ & $\begin{array}{l}0 \\
60\end{array}$ & ${ }_{0}^{17}$ & $\begin{array}{l}0 \\
0\end{array}$ & $\begin{array}{l}0 \\
45\end{array}$ & $\begin{array}{l}0 \\
0 \\
0\end{array}$ & $\begin{array}{l}\mathrm{PH} \\
\mathrm{S}\end{array}$ & $\begin{array}{l}\text { SA, IT } \\
\text { E }\end{array}$ \\
\hline 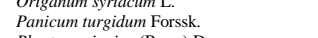 & 0 & 0 & 60 & ${ }_{0}^{0}$ & 0 & 9 & 0 & s & SA, IT \\
\hline $\begin{array}{l}\text { Plantago sinaica (Barn.) Decne. } \\
\text { Plulcicari ninisa Lam.) DC. }\end{array}$ & ${ }_{14}^{0}$ & $\begin{array}{l}0 \\
0\end{array}$ & ${ }_{0}^{0}$ & ${ }_{50}^{0}$ & $\begin{array}{l}0 \\
0\end{array}$ & $\begin{array}{l}36 \\
0\end{array}$ & 50 & $\mathrm{~s}$ & $\begin{array}{l}\text { ME } \\
\text { SA IT }\end{array}$ \\
\hline $\begin{array}{l}\text { Pulicaria incisa (Lam.). DC. } \\
\text { Thymus decussastus Benth. }\end{array}$ & 0 & 0 & 0 & 0 & 0 & 27 & 33 & s & \\
\hline 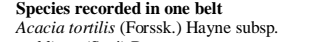 & 43 & 0 & 0 & 0 & 0 & 0 & 0 & $\mathrm{~T}$ & SA, SZ \\
\hline 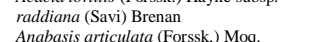 & & & & & & & & s & (2, \\
\hline $\begin{array}{l}\text { Anababsis articiculata (Forssk.) Moq. } \\
\text { Caralluma sinaica (Decne.) Benth. \& } \\
\text { trok }\end{array}$ & 14 & 0 & 0 & 0 & 0 & 0 & 0 & PH & E \\
\hline $\begin{array}{l}\text { Hook. } \\
\text { Chrozhora oblongifolia (Delile) } \\
\text { Srreng }\end{array}$ & 29 & 0 & 0 & 0 & 0 & 0 & 0 & $\mathrm{~s}$ & $\mathrm{SA}, \mathrm{SZ}$ \\
\hline $\begin{array}{l}\text { Spreng. } \\
\text { Citrullus colocynthis (L.) Schrad. }\end{array}$ & 71 & 0 & 0 & 0 & 0 & 0 & 0 & PH & ME, SA, IT \\
\hline $\begin{array}{l}\text { Datura stramonium } \mathrm{L} \text { - } \\
\text { Farsetita aepyntiara }\end{array}$ & ${ }_{29}^{14}$ & $\begin{array}{l}0 \\
0\end{array}$ & $\begin{array}{l}0 \\
0\end{array}$ & $\begin{array}{l}0 \\
0\end{array}$ & $\begin{array}{l}0 \\
0\end{array}$ & $\begin{array}{l}0 \\
0\end{array}$ & $\begin{array}{l}0 \\
0\end{array}$ & $\begin{array}{l}\mathrm{AH} \\
\mathrm{A}\end{array}$ & $\begin{array}{l}\text { PAN } \\
\text { SA, SZ }\end{array}$ \\
\hline 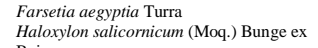 & 14 & $\begin{array}{l}0 \\
0\end{array}$ & ${ }_{0}^{0}$ & 0 & 0 & 0 & 0 & s & $\begin{array}{l}\text { SA, SL } \\
\text { SA, IT }\end{array}$ \\
\hline $\begin{array}{l}\text { Boiss. } \\
\text { Helianthemum kahiricum Delile }\end{array}$ & & & & & 0 & 0 & 0 & & \\
\hline 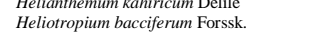 & 14 & 0 & 0 & 0 & 0 & 0 & 0 & s & SA, SU \\
\hline $\begin{array}{l}\text { Hyoscyamus boveanus (Dunal) Asch. \& } \\
\text { Schweiff }\end{array}$ & 29 & 0 & 0 & 0 & 0 & 0 & 0 & PH & $\mathrm{SA}$ \\
\hline 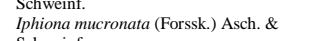 & 14 & 0 & 0 & 0 & 0 & 0 & 0 & $\mathrm{~s}$ & $\mathrm{SA}, \mathrm{SZ}$ \\
\hline $\begin{array}{l}\text { Schweinf. } \\
\text { Lavandula pubescens Decne. }\end{array}$ & 14 & 0 & 0 & 0 & 0 & 0 & & PH & \\
\hline Reseda decursiva Forssk. & 43 & 0 & 0 & 0 & 0 & 0 & 0 & $\mathrm{AH}$ & SA \\
\hline 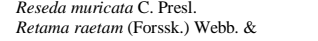 & $\begin{array}{l}144 \\
100\end{array}$ & $\begin{array}{l}0 \\
0 \\
0\end{array}$ & $\begin{array}{l}0 \\
0\end{array}$ & $\begin{array}{l}0 \\
0\end{array}$ & $\begin{array}{l}0 \\
0\end{array}$ & $\begin{array}{l}0 \\
0\end{array}$ & $\begin{array}{l}0 \\
0\end{array}$ & $\begin{array}{l}\mathrm{PH} \\
\mathrm{S}\end{array}$ & $\begin{array}{l}\text { SA } \\
\text { SA, IT }\end{array}$ \\
\hline $\begin{array}{l}\text { Berthel. } \\
\text { Rumex dentatus } \mathrm{L} \text {. }\end{array}$ & 29 & 0 & 0 & 0 & 0 & 0 & 0 & $\mathrm{AH}$ & \\
\hline $\begin{array}{l}\text { Tribulus serrestrtisi } \mathrm{L} . \\
\text { Trichodesma Aricana (L) R.Br. }\end{array}$ & $1{ }_{43}^{14}$ & $\begin{array}{l}0 \\
0\end{array}$ & $\begin{array}{l}0 \\
0\end{array}$ & $\begin{array}{l}0 \\
0\end{array}$ & $\begin{array}{l}0 \\
0 \\
0\end{array}$ & $\begin{array}{l}0 \\
0\end{array}$ & $\begin{array}{l}0 \\
0\end{array}$ & ${ }_{\mathrm{AH}}^{\mathrm{AH}}$ & $\begin{array}{l}\text { SA, SZ } \\
\text { SA, SZ }\end{array}$ \\
\hline 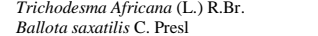 & $\begin{array}{l}43 \\
0\end{array}$ & $\begin{array}{l}0 \\
0 \\
0\end{array}$ & $\begin{array}{l}0 \\
40\end{array}$ & $\begin{array}{l}0 \\
0 \\
0\end{array}$ & $\begin{array}{l}0 \\
0\end{array}$ & $\begin{array}{l}0 \\
0\end{array}$ & 0 & $\begin{array}{l}\mathrm{AH} \\
\mathrm{s}\end{array}$ & $\begin{array}{l}\text { SA, SZ } \\
\text { ME }\end{array}$ \\
\hline & 0 & 0 & 0 & 33 & 0 & 0 & 0 & s & SA \\
\hline 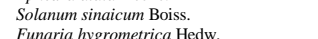 & 0 & 0 & $\begin{array}{l}0 \\
0\end{array}$ & ${ }_{0}^{0}$ & 75 & 0 & $\begin{array}{l}0 \\
0\end{array}$ & s & SA, IT \\
\hline 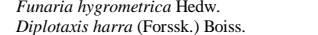 & 0 & 0 & 0 & 0 & 0 & 0 & 17 & $\begin{array}{l}\text { AH } \\
\text { PH }\end{array}$ & $\begin{array}{l}\text { SAE. IT } \\
\text { SA }\end{array}$ \\
\hline
\end{tabular}




\section{APPENDIX (2)}

\section{Salama et al.}

Summary of indicator species analysis (ISA) showing the most significant indicator species per cluster group. Relative abundance (RA), relative frequencies (RF), indicator values (IV\% of perfect

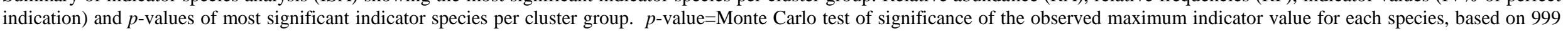
randomisations). Highest indicator values are in bold type. Abbreviations in Fig. 5, are the first three letters of the genus and the species.

\begin{tabular}{|c|c|c|c|c|c|c|c|c|c|c|c|c|c|c|c|c|c|c|c|}
\hline \multirow{3}{*}{ Species } & RA & & & & & & RF & & & & & & IV & & & & & \multirow{3}{*}{$\begin{array}{l}p \text { - } \\
\text { value }\end{array}$} & \multirow{3}{*}{$\begin{array}{l}\text { Species } \\
\text { abbreviation }\end{array}$} \\
\hline & Gro & & & & & & Group & & & & & & Group & & & & & & \\
\hline & A & в & C & D & E & F & A & B & $\mathrm{C}$ & D & E & $\mathrm{F}$ & A & В & C & D & E & & \\
\hline
\end{tabular}

\begin{tabular}{|c|c|c|c|c|c|c|c|c|c|c|c|c|c|c|c|c|c|c|c|c|}
\hline \multirow{2}{*}{$\begin{array}{l}\text { Group A } \mathbf{8} 8 \\
\text { significant indicator } \\
\text { species } \\
\text { Ochradenus baccatus } \\
\text { Delile } \\
\text { Retama raetam } \\
\text { (Forss.) Webb. \& } \\
\text { Berthel } \\
\text { Fagonia mollis Delile }\end{array}$} & 50 & 0 & 50 & 0 & 0 & 0 & 100 & 0 & 100 & 0 & 0 & 0 & 50 & 0 & 50 & 0 & 0 & 0 & 0.004 & \multirow{2}{*}{$\begin{array}{l}\text { Och bac } \\
\text { Ret rae }\end{array}$} \\
\hline & 100 & 0 & 0 & 0 & 0 & 0 & 100 & 0 & 0 & 0 & 0 & 0 & 100 & 0 & 0 & 0 & 0 & 0 & 0.002 & \\
\hline $\begin{array}{l}\text { Anabasis articulatata } \\
\text { (Forsk.) Moq. }\end{array}$ & 100 & 0 & 0 & 0 & 0 & 0 & 71 & 0 & 0 & 0 & 0 & 0 & 71 & 0 & 0 & 0 & 0 & 0 & 0.002 & Ana art \\
\hline $\begin{array}{l}\text { Citrullus colocynthis } \\
\text { (L.) Schrad. }\end{array}$ & 100 & 0 & 0 & 0 & 0 & 0 & 71 & 0 & 0 & 0 & 0 & 0 & 71 & 0 & 0 & 0 & 0 & 0 & 0.002 & Cit col \\
\hline $\begin{array}{l}\text { Trichodesma } \\
\text { atricum }\end{array}$ & 100 & 0 & 0 & 0 & 0 & 0 & 43 & 0 & 0 & 0 & 0 & 0 & 43 & 0 & 0 & 0 & 0 & 0 & 0.010 & Tri afr \\
\hline
\end{tabular}

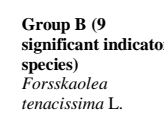

tencome arabicica L.

Fagonia schimperi
Presl.

Presl.
Verbascum sinaiticum
Benth.

Cynodon dactylon (L)

Hyoscyamus muticus

Alkanna orientalis (L)

Matsthiola longipetala
(vent.) DC.

Scrophularia deserti
Delile

28

58
74
68
46
46
74
46
54
59

$\begin{array}{ll}0 & 0 \\ 0 & 0 \\ 0 & 0 \\ 0 & 30 \\ 0 & 0 \\ 0 & 0 \\ 15 & 11 \\ 18 & 28 \\ 0 & 41\end{array}$

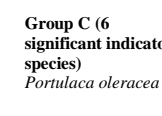

Phlomis aurea Decne

Pers.
Origanum syriacu
(Boiss.) Greater \&

(Boiss.) Greater \&
Burdet.
Panicun turgidum

$\begin{array}{llll}39 & 52 & 0 & 0 \\ 26 & 33 & 16 & 25 \\ 0 & 48 & 0 & 7 \\ 0 & 67 & 0 & 33 \\ 0 & 91 & 0 & 9\end{array}$

$\begin{array}{ll}43 & 6 \\ 29 & 8 \\ 29 & 6 \\ 29 & \\ 14 \\ 14 \\ 0 \\ 0 \\ 0\end{array}$

$\begin{array}{lllll}60 & 0 & 0 & 0 & 0 \\ 80 & 0 & 0 & 0 & 0 \\ 60 & 0 & 0 & 0 & 0 \\ 100 & 0 & 0 & 65 & 25 \\ 80 & 80 & 0 & 0 & 0 \\ 40 & 0 & 0 & 0 & 0 \\ 100 & 60 & 33 & 24 & 0 \\ 100 & 0 & 33 & 53 & 0 \\ 60 & 0 & 0 & 41 & 0\end{array}$

0.012

0.002

0.030

0.046

0.006

0.002

0.040

triafr 
Vegetation patterns and floristic composition on Jabal Musa

\begin{tabular}{|c|c|c|c|c|c|c|c|c|c|c|c|c|c|c|c|c|c|c|c|c|}
\hline \multirow{3}{*}{ Species } & \multirow{2}{*}{\multicolumn{6}{|c|}{$\begin{array}{l}\text { RA } \\
\text { Group }\end{array}$}} & \multirow{2}{*}{\multicolumn{6}{|c|}{$\begin{array}{l}\mathrm{RF} \\
\text { Group }\end{array}$}} & \multirow{2}{*}{\multicolumn{6}{|c|}{$\begin{array}{l}\text { IV } \\
\text { Group }\end{array}$}} & \multirow{3}{*}{$\begin{array}{l}p- \\
\text { value } \\
\text { A }\end{array}$} & \multirow{3}{*}{$\begin{array}{l}\text { Species } \\
\text { abbreviations }\end{array}$} \\
\hline & & & & & & & & & & & & & & & & & & & & \\
\hline & A & в & $\mathrm{c}$ & D & E & $\mathrm{F}$ & A & в & C & D & $\mathrm{E}$ & F & A & в & $\mathrm{c}$ & D & E & $\mathrm{F}$ & & \\
\hline $\begin{array}{l}\text { Ballota saxatilis } \mathrm{C} . \\
\text { Presl. }\end{array}$ & 0 & 0 & 100 & 0 & 0 & 0 & 0 & 0 & 40 & 0 & 0 & 0 & 0 & 0 & 40 & 0 & 0 & 0 & 0.042 & Bal sax \\
\hline \multicolumn{21}{|l|}{$\begin{array}{l}\text { Group D (4 } \\
\text { significant indicator } \\
\text { species) }\end{array}$} \\
\hline & 36 & 0 & 0 & 64 & 0 & 0 & 29 & 0 & 0 & 50 & 0 & 0 & 10 & 0 & 0 & 32 & 0 & 0 & 0.062 & Mal par \\
\hline $\begin{array}{l}\text { Tanacectum sinaicum } \\
\text { (Fresen.) Delile }\end{array}$ & 0 & 0 & 19 & 32 & 26 & 24 & 0 & 0 & 60 & 100 & 82 & 75 & 0 & 0 & 11 & 32 & 21 & 18 & 0.022 & Tan sin \\
\hline $\begin{array}{l}\text { Nepeta septemcrenata } \\
\text { Benth. }\end{array}$ & 0 & 0 & 0 & 71 & 29 & 0 & 0 & 0 & 0 & 100 & 41 & 0 & 0 & 0 & 0 & 71 & 12 & 0 & 0.022 & Nep sep \\
\hline \multicolumn{21}{|l|}{$\begin{array}{l}\text { Group E (2 } \\
\text { significant indicator } \\
\text { species) }\end{array}$} \\
\hline $\begin{array}{l}\text { Plantagos sisacica } \\
\text { (Barneoud) Decne. }\end{array}$ & 0 & 0 & 0 & 0 & 100 & 0 & 0 & 0 & 0 & 0 & 41 & 0 & 0 & 0 & 0 & 0 & 41 & 0 & 0.018 & Pla sin \\
\hline \multicolumn{21}{|l|}{$\begin{array}{l}\text { Group F (8 } \\
\text { significant indicator } \\
\text { species) }\end{array}$} \\
\hline $\begin{array}{l}\text { Ballota undulata } \\
\text { (Fresen.) Benth. }\end{array}$ & 0 & 13 & 19 & 27 & 9 & 32 & 0 & 40 & 60 & 83 & 29 & 100 & 0 & 5 & 12 & 22 & 3 & 32 & 0.040 & Bal und \\
\hline $\begin{array}{l}\text { Gymnocarpos } \\
\text { decandrus Forssk. }\end{array}$ & 0 & 0 & 26 & 0 & 8 & 66 & 0 & 0 & 40 & 0 & 12 & 100 & 0 & 0 & 11 & 0 & 1 & 66 & 0.002 & Gym dec \\
\hline $\begin{array}{l}\text { Galium sinaicum } \\
\text { (Delile ex Decne.) } \\
\text { Boiss. }\end{array}$ & 0 & 0 & 0 & 31 & 22 & 47 & 0 & 0 & 0 & 50 & 35 & 75 & 0 & 0 & 0 & 16 & 8 & 35 & 0.022 & Gal sin \\
\hline $\begin{array}{l}\text { Buffonia multiceps } \\
\text { Decne. }\end{array}$ & 0 & 0 & 0 & 0 & 81 & 19 & 0 & 0 & 0 & 0 & 18 & 75 & 0 & 0 & 0 & 0 & 3 & 61 & 0.004 & Baf mul \\
\hline Centaurea sinaica DC. & 0 & 0 & 0 & 0 & 100 & 0 & 0 & 0 & 0 & 0 & 24 & 75 & 0 & 0 & 0 & 0 & 6 & 57 & 0.002 & Cen sin \\
\hline $\begin{array}{l}\text { Polygala sinaica } \\
\text { Botsch. }\end{array}$ & 0 & 0 & 0 & 0 & 24 & 76 & 0 & 0 & 0 & 0 & 24 & 75 & 0 & 0 & 0 & 0 & 6 & 57 & 0.002 & Pol sin \\
\hline $\begin{array}{l}\text { Solanum sinaicum } \\
\text { Boiss. }\end{array}$ & 0 & 0 & 0 & 0 & 0 & 100 & 0 & 0 & 0 & 0 & 0 & 75 & 0 & 0 & 0 & 0 & 0 & 75 & 0.004 & Sol sin \\
\hline
\end{tabular}


أنماط الغطاء النباتي والتركيب الفلوري مع التدرج في الأرتفاع علي جبل موسي في جنوب سيناء بمصر

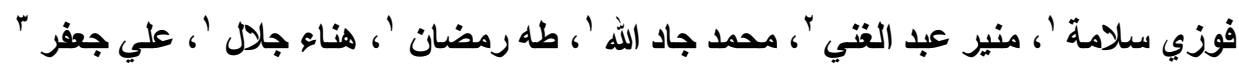

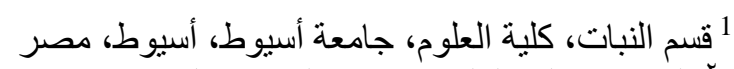

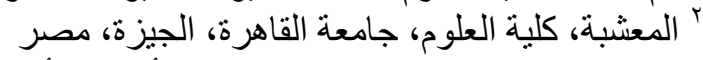

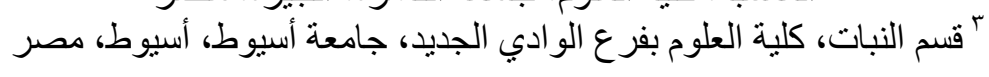

الملخص العربي

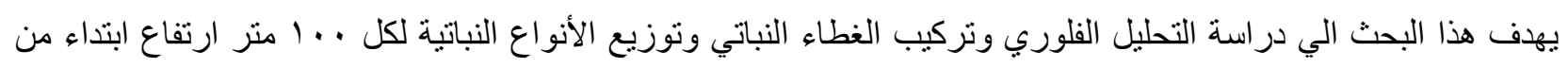

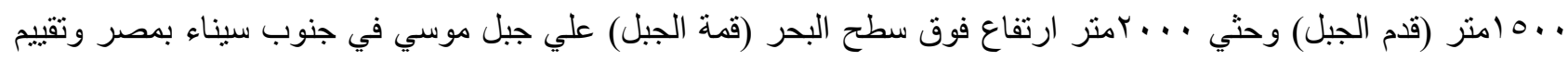

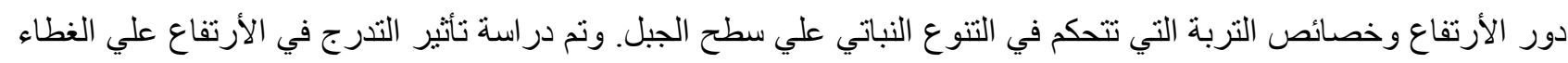

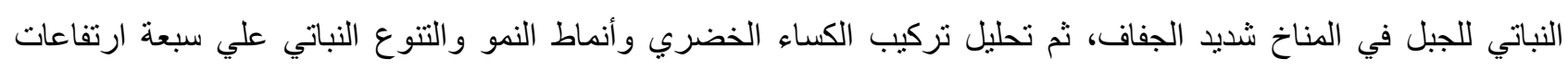

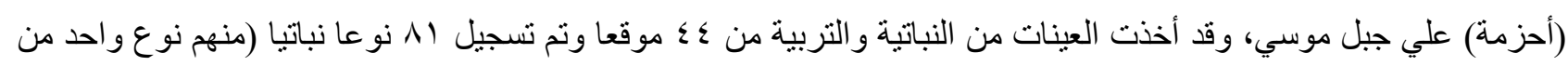

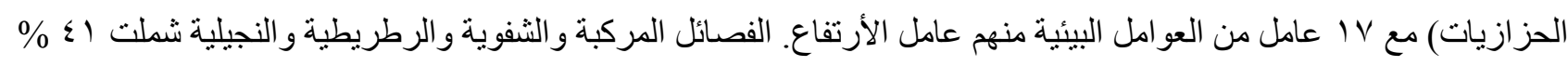

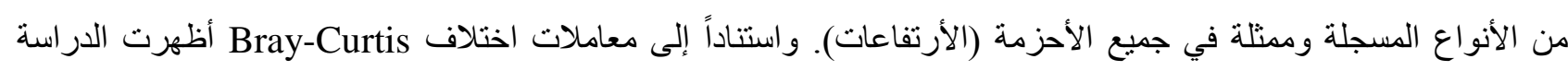

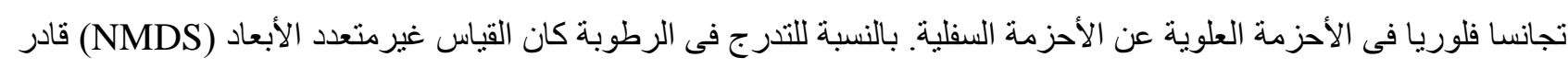

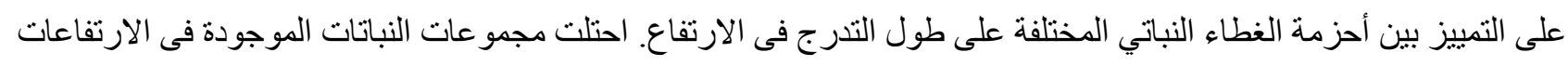

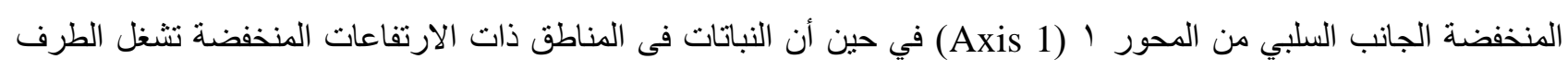

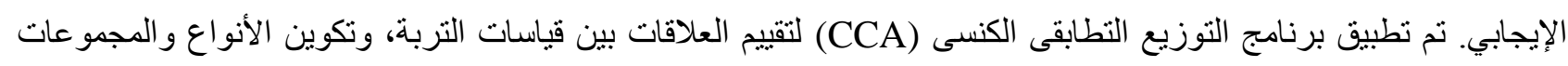

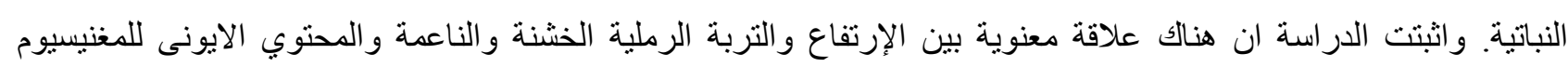
و البيكربونات مع مؤشر ات التتوع أكثر من غير ها. 